\title{
LUKASZ RADULSKI
}

ORCID: 0000-0001-9710-4225

\section{KOSZARY I INFRASTRUKTURA SZKOLENIOWA PODLASKIEJ BRYGADY KAWALERII 1937-1939. WYBRANE ASPEKTY}

DOI: $10.15290 /$ sp.2020.28.07

\begin{abstract}
Abstrakt. Artykuł stanowi przyczynek do dziejów bazy kwaterunkowej i szkoleniowej kawalerii Wojska Polskiego okresu II Rzeczypospolitej. Autor szczegółowo przedstawił wspomniane kwestie na przykładzie Podlaskiej Brygady Kawalerii - w ostatnim stadium jej pokojowego funkcjonowania, to znaczy w latach 1937-1939.
\end{abstract}

Słowa kluczowe: budownictwo wojskowe, Garnizon Białystok, Wojsko Polskie 1921-1939, koszary

\begin{abstract}
The article is an addendum to the history of housing and training facilities of the Polish Armed Forces of the Second Polish Republic. The author takes a closer look at the aforementioned themes by investigating the case of the Podlaska Cavalry Brigade in years 1937-1939, a time of its peacetime activity prior to the outbreak of World War II.
\end{abstract}

Key words: military buildings, Białystok Garrison, Polish Armed Forces 1921-1939, barracks

Podlaska Brygada Kawalerii była jednym z 11 związków taktycznych kawalerii Wojska Polskiego w przededniu wybuchu II wojny światowej. Swój rodowód wywodziła z VI Brygady Jazdy czasów wojny polsko-rosyjskiej 1920 r., która w pierwszej dekadzie niepodległej Rzeczpospolitej przechodziła kolejne transformacje, funkcjonując $\mathrm{w}$ strukturze sił zbrojnych kolejno jako VIII i XVIII Brygada Kawalerii w ramach 1. Dywizji Kawalerii. W 1929 r. została przeobrażona w samodzielną Brygadę Kawalerii „Białystok”, zaś 1 kwietnia 1937 r. nastąpiła ostatnia poważniejsza zmiana struktury kawalerii. Odtąd BK „Białystok” nosiła miano Podlaskiej Brygady Kawalerii ${ }^{1}$. Równo-

1 Centralne Archiwum Wojskowe Wojskowego Biura Historycznego [dalej: CAW], Generalny Inspektorat Sił Zbrojnych [dalej: GISZ], I.302.4.1282, Meldunek 1.dz.899.tj.37 z III 1937 r. szefa Biura Inspekcji GISZ płk. dypl. L. Strzeleckiego do gen. dyw. Rómmla i gen. bryg. Kwaśniewskiego w sprawie zmiany podległości 1. i 5. puł.; CAW, Departament Kawalerii 
cześnie rozpoczął się proces zwiększania siły ogniowej: zorganizowano pododdziały armat przeciwpancernych, kolarzy itp. Niezależnie od wewnętrznej organizacji wymienionych uprzednio związków taktycznych kawalerii, będących atentatami Podlaskiej BK, cechą wspólną było przywiązanie do Białegostoku jako miejsca postoju dowództwa (z krótką przerwą w połowie lat dwudziestych) oraz podległość 10. Pułku Ułanów Litewskich, od 1922 r. na stałe związanego ze stolicą województwa podlaskiego. W ostatnim stadium organizacyjnym (czasu pokoju) brygadę tworzyły również: 5. Pułk Ułanów Zasławskich z Ostrołęki, 9. Pułk Strzelców Konnych im. gen. Kazimierza Pułaskiego z Grajewa i Osowca, 14. dywizjon artylerii konnej z Białegostoku i Ostrołęki, 1. szwadron pionierów (Białystok, później Ostrołęka) i 10. szwadron łączności (Białystok). Artykuł zawężony został do ujęcia tematu w zakresie ograniczonym garnizonami wymienionych powyżej oddziałów, pomija przewidziane planem mobilizacyjnym elementy, które miały znaleźć się w składzie brygady po ukończonej mobilizacji i koncentracji.

Niniejszy tekst stanowi próbę usystematyzowania wiedzy na temat warunków koszarowych i infrastruktury szkoleniowej Podlaskiej BK po reorganizacji z wiosny 1937 r. Dotychczas zagadnienie to - w kontekście całej kawalerii II RP - nie cieszyło się szerszym zainteresowaniem badaczy. Pojawiały się co prawda bardziej lub mniej szczegółowe opisy kompleksów koszarowych w monografiach pułków kawalerii - docenić należy działania na tym polu Szymona Kucharskiego, publikującego m.in. w serii „Wielka Księga Kawalerii Polskiej”. Problematyka bytu i infrastruktury szkoleniowej kawalerii ulega zatarciu $\mathrm{w}$ tematach pobocznych, mających zdecydowanie mniejsze znaczenie dla efektywności bojowej wojsk, m.in.: w życiu społecznym miast garnizonowych, obchodach świąt itp. Nie natrafiłem również na próby ujęcia tego zagadnienia z punktu widzenia wielkich jednostek kawalerii, toteż obecny stan wiedzy należy uznać za niezadowalający.

Czynnikiem w pewnej mierze usprawiedliwiającym powyższą sytuację jest stan zachowania kompleksów koszarowych. Część ocalałych obiektów znajduje się dziś poza wschodnią granicą Rzeczypospolitej, co w oczywisty sposób utrudnia do nich dostęp. Te, które znalazły się w granicach Polski, przechodziły różne koleje. Niektóre po 1945 r. były i nadal są użytkowane

MSWojsk. [dalej: Dep. Kaw. MSWojsk.], I.300.30.39, Nadanie nazw wielkim jednostkom kawalerii; CAW, Oddział I Sztabu Głównego [dalej: O I SG], I.303.3.49, Pismo Departamentu Dowodzenia Ogólnego [dalej: DDO] MSWojsk. L. 1426/Org.Tjn. z 4 III 1937 r. wg rozdzielnika w sprawie zmiany podległości 1. puł.; CAW, O I SG, I.303.3.49, Pismo DDO MSWojsk. L.1429/Org.Tjn. z 4 III 1937 r. wg rozdzielnika w sprawie zmian w składach osobowych jednostek kawalerii, zał. 1, 2 i 3. 
przez Wojsko Polskie i inne formacje mundurowe; kompleksy te zazwyczaj prezentują najlepszy stan zachowania, chociaż dostęp do nich - ze zrozumiałych względów - jest ograniczony. Inne, jak zespół koszarowy w Ostrołęce-Wojciechowicach, uległy poważnym zniszczeniom wojennym² ${ }^{2}$, część ocalałych obiektów rozebrano po 1945 r. W innych przypadkach destrukcja założeń koszarowych wiązała się $\mathrm{z}$ inwestycjami budowlanymi. Rzadka jest sytuacja obiektów piechoty i artylerii w Zambrowie, które w dużym stopniu zachowały oryginalną formę do czasów współczesnych ${ }^{3}$. Warto tu zaznaczyć, że w Polsce dostrzegalne jest stosunkowo niewielkie zainteresowanie wartościami historycznymi kompleksów koszarowych, dostosowywanych do nowych funkcji ${ }^{4}$. Instytucje państwowe odpowiedzialne za konserwację zabytków, tudzież lokalne środowiska historyków i pasjonatów, nie zawsze zdołały dokonać inwentaryzacji i zabezpieczenia ocalałych po wojnie zabudowań koszarowych. Badacz, usiłujący szukać informacji w zasobach archiwalnych, natyka się na istotny problem $\mathrm{z}$ powodu zniszczenia i znacznego rozproszenia ocalałych materiałów źródłowych. Przykładem może być szczątkowe zachowanie akt Brygady Kawalerii „Białystok”/Podlaskiej Brygady Kawalerii (zachowała się jedynie niepełna dokumentacja z lat 1930-19335), przechowywanych w Centralnym Archiwum Wojskowym Wojskowego Biura Historycznego. Istotny zasób informacji znajduje się w aktach Departamentu Budownictwa i Departamentu Kawalerii Ministerstwa Spraw Wojskowych; $\mathrm{w}$ tym przypadku dokończenie rozpoczętej kwerendy uniemożliwił mi wybuch epidemii w marcu 2020 r. Niniejszy artykuł nie aspiruje do miana całościowego ujęcia zagadnienia. Mam jednak nadzieję, że będzie stanowił punkt wyjściowy oraz inspirację do dalszych badań nad warunkami bytowo-szkoleniowymi oddziałów kawalerii Wojska Polskiego oraz ich wpływem na proces szkolenia i efektywność bojową.

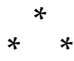

2 J. Kazimierski, Straty biologiczne i materialne na obszarze obecnego województwa ostrołęckiego w latach II wojny światowej, „Rocznik Mazowiecki” 1998, t. 10, s. 84-86.

3 www.koszary.zambrow.org.

4 Np. przebudowa i adaptacja koszarów 15. puł. w Poznaniu w 2007 r., gdzie starano się zachować tożsamość historyczną miejsca, czy też adaptacja na Hotel Loft 1898 budynku koszarowego przy ul. Pułaskiego w Suwałkach w 2015 r., gdzie od frontu dobudowano współczesne skrzydło, ale nadal czytelne są wartości historyczne obiektu. D. Gawryluk, Wspótczesne modernizacje zabytkowych zespołów koszarowych - analiza wybranych realizacji na terenie Polski, „Teka Komisji Architektury, Urbanistyki i Studiów Krajobrazowych” [dalej: „TKAUiSK"] 2015, t. XI, nr 1, s. 68, 71.

5 CAW, Brygady i Dywizje Kawalerii, I.314.15.1. 
Niepodległa II Rzeczpospolita została zmuszona do wykorzystania na potrzeby armii ocalałych obiektów wojskowych po państwach zaborczych. Oddziały Podlaskiej BK stacjonowały w sześciu kompleksach koszarowych w czterech miejscowościach, stanowiących przed rokiem 1914 miejsca dyslokacji oddziałów rosyjskich: Białymstoku, Ostrołęce, Grajewie i Osowcu. Warto podkreślić, że koszary porosyjskie nie cieszyły się dobrą opinią. Wymagały bowiem największego nakładu prac adaptacyjnych, a powszechne używanie przez Rosjan drewna jako budulca, wymuszało szereg zabiegów konserwacyjnych i nie zapewniało odpowiednich warunków bytowych, szczególnie po latach zaniedbań z okresu 1914-1920. Kompleksy w tych miejscowościach zostały poważnie zdewastowane podczas działań wojennych, co przekładało się na bardzo złe warunki kwaterunkowe, przynajmniej w początkowym okresie pokojowego funkcjonowania Wojska Polskiego ${ }^{6}$. Ponadto obiekty te nie zawsze zapewniały odpowiednią bazę szkoleniową, co wykażę analizując zagadnienia użytkowania strzelnic i placów ćwiczeń (o ile takie w ogóle znajdowały się w pobliżu koszar), stajni i innych elementów infrastruktury, wpływających na działalność szkoleniową oddziałów brygady.

\section{Oddziały i kompleksy koszarowe Podlaskiej BK garnizonu Białystok}

Jeśli wierzyć Zygmuntowi Kosztyle, Białystok został stałym garnizonem jednostek wojskowych na początku drugiej połowy XVIII w. Miejscowość, będąca rezydencją hetmana wielkiego koronnego Jana Klemensa Branickiego, została miejscem stałego pobytu oddziałów koronnych i prywatnych stanowiących odpowiednik wzmocnionych pułków piechoty i kawalerii z pododdziałem artylerii. Badacz szacował, że oddziały te liczyły łącznie około 1500 żołnierzy, rozkwaterowanych zapewne po wynajmowanych izbach i budynkach; nie wiadomo nic o hipotetycznym powstaniu $\mathrm{w}$ tym okresie zabudowań przeznaczonych wyłącznie na potrzeby bytowe wojska. Po śmierci Branickiego w 1771 r. wojskową załogę miasta zlikwidowano7. Okres od upadku państwa polskiego do klęski w wojnie polsko-rosyjskiej

6 B. Tomecka, Zespót koszarowy przy ulicy Bema. Studium historyczno-przestrzenne opracowane na zlecenie Podlaskiego Oddziału Straży Granicznej im. gen. dyw. H. Minkiewicza, Białystok 1996, s. 12; A. Dobroński, Białystok. Historia miasta, Białystok 2001, s. 100-101; J. Chęciński, Budownictwo wojskowe w Polsce (1918-1939), Warszawa 1966, passim.

7 Archiwum Ośrodka Badań Historii Wojskowej Muzeum Wojska w Białymstoku [dalej: AOBHW], XI.3.1 (stara sygn.), Z. Kosztyła, Dzieje wojskowe Białegostoku, b.d., s. 3, 7. 
1831 r. nie pozostawił śladów obecności w mieście stałej załogi wojskowej, czy to pruskiej, rosyjskiej, francuskiej, czy polskiej. W 1843 r. obwód białostocki wcielono do guberni grodzieńskiej; w tym okresie Białystok mieścił elementy rosyjskiego garnizonu: komendę inwalidzką, dowództwo konno-etapowe, dowództwo żandarmerii, zabezpieczenie warszawskiej linii telegraficznej z podległymi pododdziałami oraz szpital wojskowy, pozostając pod względem wielkości i znaczenia garnizonu w tyle za Grodnem i Brześciem nad Bugiem ${ }^{8}$.

Podczas powstania styczniowego w rejonie Białegostoku działał rosyjski Nowoingermanlandzki Pułk Piechoty (późniejszy 10. Nowoingermanlandzki pp) z 3. Dywizji Piechoty. Jednostka bytowała w doraźnych warunkach polowych i na kwaterach prywatnych, a jej część rozlokowano podobno w bliżej niesprecyzowanych koszarach na terenie miasta, przy czym nie udało się odnaleźć jakichkolwiek informacji na temat ich lokalizacji i pojemności. Można postawić hipotezę, że mowa tu o barakach, opuszczonych po wyjeździe robotników budujących kolej warszawsko-petersburską. Zimą 1863-1864 r. pułk został rozproszony na kwatery w Białymstoku, Supraślu, Choroszczy, Surażu, Tykocinie i Wysokim Mazowieckiem. W 1865 r. w Białymstoku znajdował się sztab pułku i kilka kompanii, pozostałe rozlokowano w okolicznych miejscowościach (Choroszczy, Knyszynie, Surażu, Klepaczach, Bielsku, Goniądzu). W połowie lat sześćdziesiątych XIX w. jednostkę przeniesiono w głąb imperium, zaś do Białegostoku dotarł 13. Włodzimierski Pułk Ułanów z 7. Dywizji Kawalerii. Sztab jednostki rozlokowano w kwaterach prywatnych w mieście, dywizjony umieszczono w Janowie i Zabłudowie, chociaż mogły też czasowo kwaterować w Białymstoku. Ułani przebywali tu do 1874 r., po czym zostali przeniesieni na stałe do Kowna. W 1866 r. do Białegostoku przybyła 26. Brygada Artylerii z 26. DP; rozmieszczono ją w niewielkich koszarach przy ówczesnych ulicach Nowoszosejnej i Lipowej (ob. ul. Dąbrowskiego i Lipowa). Niewykluczone, że te obiekty zostały zbudowane metodą "gospodarczą" przez 13. Włodzimierski pułk w okresie jego pobytu w Białymstoku. Udało się jedynie ustalić, że 26. BArt. zgłaszała ogromne trudności z pomieszczeniem się w kompleksie koszarowym ${ }^{9}$. $\mathrm{W}$ połowie lat siedemdziesiątych XIX w. w mieście czasowo przebywać miał

8 Памятная книжка гродненской губерніи на 1847 годь, Гродно 1847, s. 215-255; АОВНW, XI.3.5 (stara sygn.); A. Dobroński, Dyslokacja wojsk rosyjskich na terenie obecnego województwa białostockiego (1867-1914), s. 1-2.

9 Ежегодникъ русской арміи на 1869 годъ, Санктпетербургь 1869, s. 595-596, 603; Памятная книжка гродненской губерніи на 1870 г., Гродно 1870, s. 64-87. 
również Małojarosławski Pułk Dragonów, ale informacje o nim ograniczają się do stwierdzenia, że sztab rozmieścił się "gdzieś" w mieście ${ }^{10}$. Obecność wymienionych wyżej jednostek armii rosyjskiej w Białymstoku odznaczała się doraźnością rozkwaterowania i poważnymi problemami bytowymi. Nie wydaje się jednak, by można było uznać miejscowość za stałą siedzibę garnizonu, tym bardziej, że poszczególne elementy jednostek rozproszono na kwaterach na znacznym obszarze, a w samym mieście nie odnotowano większych wojskowych inwestycji budowlanych.

Dopiero $\mathrm{w}$ drugiej połowie lat siedemdziesiątych XIX w. dała się zauważyć dążność rosyjskich władz wojskowych do rozmieszczenia na stałe w Białymstoku silniejszego garnizonu, mającego zapewnić obsadę wojskową południowo-zachodniej części Wileńskiego Okręgu Wojskowego (od 1862 od 1907 r. w ramach Warszawskiego OW). Wpływ na to miało kilka czynników, wśród których można wymienić: pamięć o niedawnym „buncie polskim" z lat 1863-1864, odczuwalne niezadowolenie społeczne i obawy przed kolejnym powstaniem, nasilenie procesu rusyfikacyjnego, czy ekonomiczny wzrost znaczenia miasta i eksplozja demograficzna wynikła m.in. z budowy kolei petersbursko-warszawskiej. Nie wolno pominąć również stałego pogarszania się relacji rosyjsko-niemieckich i ogólnego wzrostu liczebności wojsk rosyjskich wzdłuż zachodnich granic imperium, szczególnie w efekcie reform wojskowych ministra wojny feldmarszałka Dmitrija A. Milutina. Dość stwierdzić, że pomiędzy końcem siódmej dekady XIX w. a rokiem 1910 władze zaborcze wybudowały tu pięć dużych kompleksów koszarowych, znanych w II RP pod nazwami: Koszary im. R. Traugutta (użytkowane przed 1939 r. przez 42. pp), Koszary im. gen. J. Bema (14. dak), Koszary im. gen. J. Sowińskiego (m.in. dowództwo Podlaskiej BK), Koszary im. marsz. J. Piłsudskiego (10. puł.), a także tzw. koszary artyleryjskie, których katastrofalny stan zachowania po roku 1920 uniemożliwiał użytkowanie wojskowe. Aż trzy z wymienionych kompleksów przypadły oddziałom należącym do Podlaskiej BK, a jej dowódca pełnił jednocześnie funkcję komendanta garnizonu ${ }^{11}$.

Warto tu nadmienić, że chociaż każdy z użytkowanych kompleksów posiadał patrona, to żaden $\mathrm{z}$ nich nie został zatwierdzony urzędowo przez właściciela - skarb państwa via Ministerstwo Spraw Wojskowych. W Wojsku

10 R. Wróblewski, Zarys historii carskiego garnizonu w Biatymstoku w latach 1864-1914, „Militaria XX wieku" 2012, nr 1, s. 42-43.

11 Archiwum Instytutu Polskiego i Muzeum im. gen. Sikorskiego w Londynie [dalej: AIPMS], B.I.17/A/1, L. Kmicic-Skrzyński, Charakterystyka garnizonów, s. 2. 
Polskim przyjęto bowiem zasadę, że to korpus oficerski jednostki lub garnizonu występował do ministra o nadanie nazwy, identycznie jak w przypadku szefostw honorowych oddziałów ${ }^{12}$. Jako że w Białymstoku koszary funkcjonowały z patronami nieuznanymi oficjalnie, można domniemywać, że komenda garnizonu i korpusy oficerskie jednostek nie odczuwały potrzeby unormowania tej kwestii, zadowalając się powszechnym stosowaniem nazw zwyczajowych. Na chwilę obecną nie można ustalić, czy takie wnioski z garnizonu Białystok wpłynęły do ministerstwa, ani też od którego roku stosowano nazwy zwyczajowe kompleksów.

\section{a) Koszary im. gen. Sowińskiego}

Pod koniec 1879 r. Rosjanie rozpoczęli budowę koszar na południowo-wschodnim skraju Białegostoku (rejon obecnej ul. Wołodyjowskiego). Zarówno nazwa zwyczajowa obiektu („Włodzimierskie”) jak i ulicy, przy której go zbudowano, przejęły miano od nazwy jednostki, która została w nim ulokowana - 61. pp. Kompleks o powierzchni 5 ha (?) powstawał w znacznej mierze metodą gospodarczą, tzn. budowa postępowała nakładem pracy oddziałów, kwaterujących w pobliżu w improwizowanych warunkach lub kwaterach prywatnych, a nadzór nad inwestycją sprawował lokalny Zarząd Wojenno-Inżynieryjny. Gros zabudowy w momencie oddania do użytku w roku 1883, nawet wedle ówczesnych norm należy uznać za przestarzały, szczególnie tyczyło się to 15 drewnianych baraków na 130 żołnierzy każdy. Odznaczały się one ciasnotą i uniemożliwiały utrzymanie odpowiedniego poziomu higieny. Centrum zajmował duży plac apelowy, zaś na południe od niego rozmieszczono jednokondygnacyjne, murowane budynki sztabowe, magazynowe i szpitalne (lazaret garnizonowy) oraz niewielkie osiedle oficerskie. Ta grupa obiektów wyróżniała się wyższym standardem technologicznym i sanitarnym. W sumie na terenie kompleksu w ciągu kilku lat zbudowano ponad 40, w większości drewnianych budynków. Latem $1883 \mathrm{r}$. do Białegostoku zaczęto przegrupowywać elementy 16. DP, przy czym dowództwa i sztaby dywizji i obu jej brygad piechoty zakwaterowano w wynajętych budynkach w mieście, tj. w tzw. Domu Gorodskiej przy ul. Polowej (ob. Waryńskiego), później w tzw. Domu Satina przy ul. Staroszosejnej (ob. św. Rocha). Natomiast w samych koszarach rozmieszczono 61. Włodzimierski pp. Pomiędzy 1890 a 1913 r. koszary rozbudowano, dodając

12 R. E. Stolarski, Nazwy obiektów wojskowych w II Rzeczypospolitej, „Mars” 1993, nr 1, s. 170-171, $175,178-179$. 
m.in. pomieszczenia dla kompanii karabinów maszynowych oraz murowany, dwukondygnacyjny budynek dla przeniesionego z Łomży dowództwa VI Korpusu. Do czasu ukończenia obiektu sztabowego (nie wcześniej niż w 1913 r.) dowództwo korpusu rozmieściło się w kwaterach przy ul. Niemieckiej (ob. Kilińskiego). W 1910 r. 61. Włodzimierski pp został relokowany do Osowca, a jego miejsce w koszarach zajęły inne oddziały - przeniesiony z Hornostajów (na północ od Moniek) III batalion 62. Suzdalskiego pp oraz III i IV bataliony 63. Uglickiego pp z Sokółki ${ }^{13}$.

Niewiele wiadomo na temat użytkowania koszar przez niemieckie wojska okupacyjne w latach 1915-1919. Wydaje się, że Niemcy w większym stopniu wykorzystywali inne, nowocześniejsze budowle wojskowe Białegostoku. Faktem jest, że drewniane budynki koszar „włodzimierskich” po przejęciu przez Wojsko Polskie znajdowały się w fatalnym stanie, co wynikało $\mathrm{w}$ równej mierze $\mathrm{z}$ dewastacji przeprowadzanej przez kolejnych okupantów, jak i z braku odpowiednich czynności konserwacyjnych. Nie istnieją również bliższe dane, pokazujące $\mathrm{w}$ jaki sposób kompleks został wykorzystany podczas krótkotrwałej obecności wojsk bolszewickich latem 1920 r., szczególnie w kontekście zamiaru wykorzystania miejscowości jako ośrodka formowania Polskiej Armii Czerwonej. Potwierdzona jest obecność w Białymstoku elementów bolszewickiej 52. Dywizji Strzeleckiej Romana Lągwy (uprzednio funkcjonującej jako polska Zachodnia Dywizja Strzelecka) ${ }^{14}$. Po odzyskaniu miasta przez Wojsko Polskie rozpoczęto - na miarę bardzo skromnych środków - prace renowacyjne, doprowadzając koszary do stanu używalności. Problematyczne było wykorzystanie drewnianych baraków, które uległy procesom gnilnym i zagrzybieniu.

Adaptacja i wykorzystanie budynków porosyjskich koszar, w II RP nieoficjalnie nazwanych Koszarami im. gen. Józefa Sowińskiego, następowały stopniowo. $Z$ pewnością inwestycjom budowlanym nie sprzyjały stosunkowo częste zmiany podległości $\mathrm{w}$ dziedzinie administracyjno-gospodarczej $^{15}$. Również przeniesienie w 1924 r. powiatu Białystok z obszaru

13 Wg etatu pokojowego pułk składał się ze sztabu, 4 batalionów po 4 kompanie i kompanii gospodarczej, liczących razem - 70 oficerów i 1899 szeregowych. R. Wróblewski, op. cit., s. $44,48,50-51$.

AOBHW, XI.3.1 (stara sygn.), Z. Kosztyła, op. cit., s. 10.

15

M.in. w 1921 r. Dowództwo Okręgu Generalnego Białystok podporządkowano 2. Armii, która do 1922 r. pozostawała na etacie wojennym z ośrodkami służb w Lidzie, Grodnie, Mołodecznie i Święcianach. Jej podległość gospodarcza bezpośrednio pod MSWojsk. praktycznie wykluczała inwestycje budowlane. CAW, O I SG, I.303.3.154, Pismo O I SG L.dz. 10932/Mob. z 19 VIII 1921 r. w sprawie zależności służbowej DOG Białystok. 


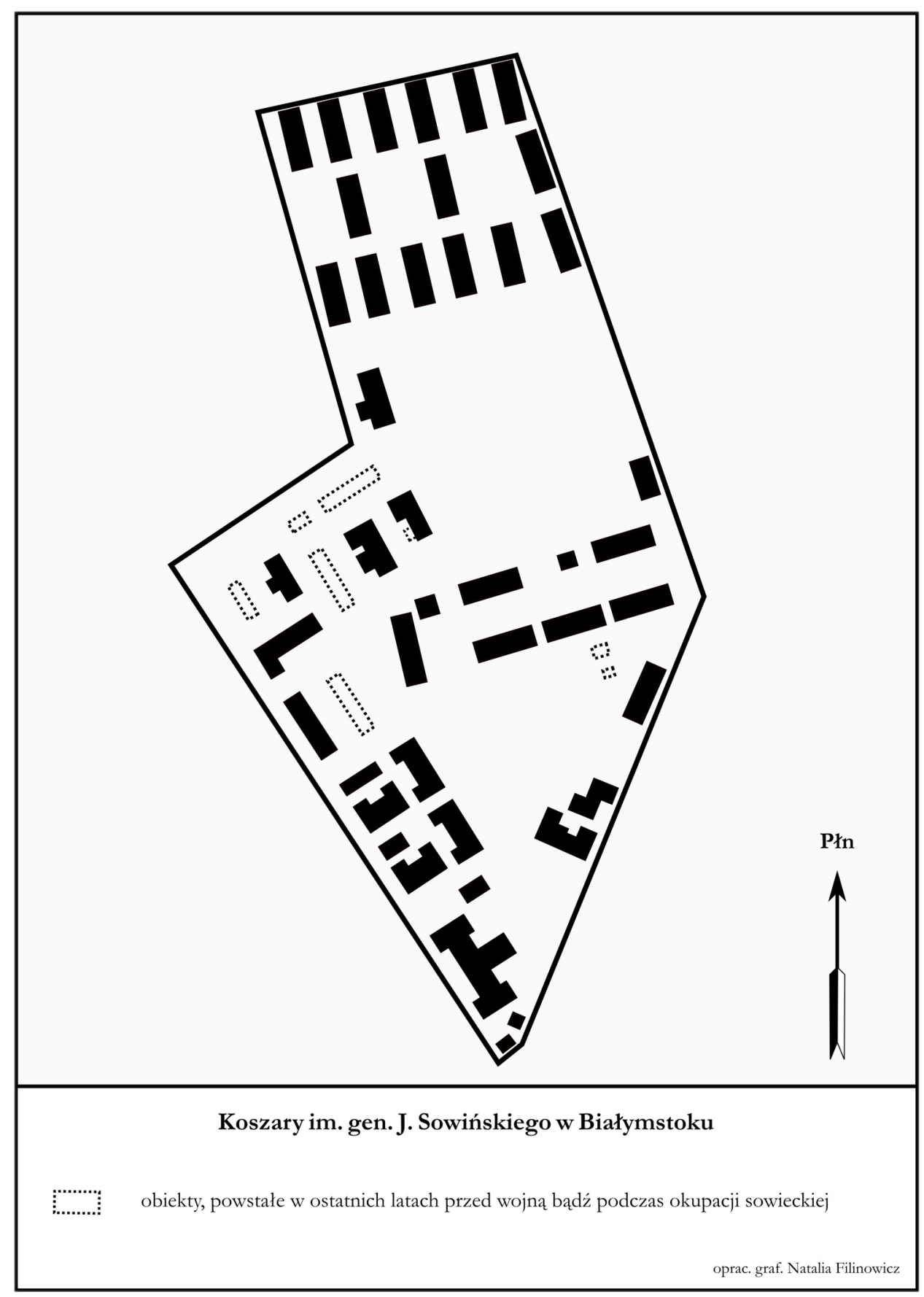


podległego dowódcy Okręgu Korpusu nr I Warszawa do Okręgu III w Grodnie zahamowało na pewien czas inwestycje, utrudniane dodatkowo niejasnym podziałem kompetencji między departamentami Ministerstwa Spraw Wojskowych oraz różnorodnymi niedociągnięciami w dziedzinie wykorzystania kredytów na konserwację i fundusz remontowy ${ }^{16}$. Jeszcze w połowie lat trzydziestych XX w. niektóre z obiektów Koszar im. gen. Sowińskiego pozostawały niewykorzystane, przy czym na chwilę obecną nie jest możliwe wskazanie, czy pozostawiono je opuszczone, czy też w jakikolwiek sposób dbano o podtrzymanie możliwości użytkowania.

W 1933 r. komendant garnizonu i jednocześnie dowódca BK „Białystok” płk dypl. Ludwik Kmicic-Skrzyński usiłował zorientować się, czy w najbliższym czasie mogłoby dojść do sformowania szwadronu łączności dla dowodzonej przezeń wielkiej jednostki (rozbudowy dotychczasowego Oddziału Łączności brygady, rozkwaterowanego właśnie w koszarach im. gen. Sowińskiego ${ }^{17}$ ). Zapytania kierowane do przełożonych o skład organizacyjny formacji łączności motywował koniecznością przygotowania zawczasu odpowiednich pomieszczeń koszarowych, stajni, magazynów sprzętu łączności itp. obiektów. Podkreślić należy, że dowódca wykazał się czujnością w wychwytywaniu drobnych (i nie kierowanych bezpośrednio do niego) informacji oraz daleko posuniętą troską o zapewnienie odpowiednich warunków bytowych i szkoleniowych ${ }^{18}$. Ostatecznie szwadron został utworzony w 1937 r.; cały materiał użytku bieżącego oraz mobilizacyjny zdeponowano w pobliskich magazynach ${ }^{19}$.

Inwestycje budowlane lat 1921-1939 w kompleksie im. gen. Sowińskiego były bardzo skromne. W 1936 r. z połączenia izb chorych poszczególnych białostockich oddziałów powstała Garnizonowa Izba Chorych z 50 łóżkami.

16 Dziennik rozkazów MSWojsk. 1924 nr 24 poz. 360; J. S. Wojciechowski, 10. Pułk Ułanów Litewskich, Oświęcim 2014, s. 169-171; J. Chęciński, op. cit., s. 89-114.

17 CAW, Dep. Kaw. MSWojsk., I.300.30.152, BK Białystok L.dz. 555/Tjn. z 18 VI 1935 r. - Rozkaz organizacyjny do koncentracji specjalnej Oddziału Łączności BK i plutonów łączności pułków kawalerii, s. 1-3.

18 CAW, Dep. Kaw. MSWojsk., I.300.30.147, Pismo BK Białystok L.dz. 316/tj. z 20 IV 1933 r. wg rozdzielnika w sprawie szwadronów łączności przy WJ kawalerii, s. 1-2.

19 CAW, Biuro Personalne MSWojsk., I.300.18.274, Obsada oficerska Oddziału Łączności BK „Białystok”; CAW, O I SG, I.303.3.89, Pismo DDO MSWojsk. L. 854/Org.Tjn. z 16 VI 1937 r. wg rozdzielnika w sprawie organizacji jednostek łączności dla DP i BK, s. 1-2; CAW, O I SG, I.303.3.89, Dowództwo Wojsk Łączności L. 2265/Tj.I.Org.37 z 26 VII 1937 r., zał. 3; CAW, Oddział I SG, I.303.3.89, Pismo DDO MSWojsk. L.dz. 6182/Org.Tjn. z 30 XII 1936 r. wg rozdzielnika $\mathrm{w}$ sprawie organizacji plutonów łączności da BK, zał. 2 - etat dla BK Białystok. 
Przebudowano również cerkiew, konsekrując ją jako katolicką kaplicę garnizonową oraz we własnym zakresie unowocześniono obiekt hippiczno-lekkoatletyczny. Także w 1936 r. część zdatnych do użytku budynków, wykorzystywanych dotąd jako magazyny Składnicy Materiałów Intendenckich oraz magazyny zbożowe, opróżniono, przenosząc ich zawartość do nowo powstałych na północnym skraju Białegostoku magazynów. W 1937 r. wybudowano murowaną stajnię na około 50 koni dla szwadronu łączności oraz 50-metrową strzelnicę pistoletową ${ }^{20}$. Warto tu podkreślić, że koszary im. gen. Sowińskiego znajdowały się w podległości administracyjnej 10. pułku, przy czym kwestię uregulowano oficjalnie dopiero $\mathrm{w}$ ostatnim roku przed wojną; od momentu ulokowania 10. pułku w Białymstoku wszelkich prac gospodarczych dokonywano właśnie rękami ułanów.

Możliwości kwaterunkowe koszar dowódca garnizonu zamierzał wykorzystać na pomieszczenie brygadowego szwadronu kolarzy, którego sformowanie postulował przynajmniej od $1937 \mathrm{r} .{ }^{21} \mathrm{Na} 1$ kwietnia $1937 \mathrm{r}$. w kompleksie mieściły się: dowództwo Podlaskiej BK (uprzednio również dowództwa „białostockich” wielkich jednostek kawalerii), komendy garnizonu i placu Białystok, rejonowy inspektor koni, Pluton Żandarmerii Białystok, szwadron zapasowy 2. puł. z magazynami oraz 10. szwadron łączności z magazynami. Łącznie stacjonować mogło tu około 350 wojskowych i pracowników cywilnych, z czego zaledwie 3 mieszkało w kwaterach oficerskich na terenie obiektu. Porównanie tej liczby do danych zawartych w spisie powszechnym z 1897 r., który wykazał w Białymstoku około 4200 rosyjskich wojskowych, z tego niemal połowę zakwaterowanych właśnie w koszarach „włodzimierskich", najlepiej oddaje stopień zagospodarowania tego kompleksu koszarowego w końcu lat trzydziestych XX w., a tym samym poziom degradacji jego budynków w latach 1914-192122.

Ostatnią próbę rewitalizacji kompleksu przed wybuchem wojny podjął szef Departamentu Kawalerii MSWojsk. gen. bryg. Piotr Skuratowicz. Pomiędzy wiosną 1938 a wiosną 1939 r. komisja objazdowa pod jego kie-

20 CAW, Dowództwo Okręgu Korpusu [dalej: DOK] III/35, Rozkaz tajny nr 15, Grodno 27 VI 1936 r., s. 3; CAW, DOK III/35, Rozkaz tajny nr 16, Grodno 11 VII 1936 r., s. 2-3; U. Kraśnicka, Organizacja rzymskokatolickiego duszpasterstwa wojskowego na terenie DOK III Grodno w latach 1921-1939, "Zeszyt Naukowy Muzeum Wojska w Białymstoku” 1998, z. 11, s. 63; H. Mościcki, Białystok. Zarys historyczny, Białystok 1933, s. 172-173; AIPMS, B.I.17/A/1, L. Kmicic-Skrzyński, Charakterystyka garnizonów, s. 2; W. Kusiński, Rozwój przestrzenny miasta Białegostoku, „Studia i Materiały do Dziejów Miasta Białegostoku”, t. I, 1968, s. 46.

21 CAW, Dep. Kaw. MSWojsk., I.300.30.131, Dowództwo Podlaskiej BK L.dz. 1920/I.Tjn.37 z 20 XI 1937 r. - Sprawozdanie z wyszkolenia za okres letni 1937 r., s. 6.

22 AOBHW, XI.3.5 (stara sygn.), A. Dobroński, op. cit., s. 6. 
rownictwem odbyła szereg wizytacji w pułkach kawalerii na terenie całego kraju, sprawdzając stan zakwaterowania oddziałów oraz infrastrukturę bytową i szkoleniową ${ }^{23}$. Wizyta generała w głównym garnizonie Podlaskiej BK 1 marca 1939 r. wiązała się m.in. z planami zorganizowania w Białymstoku kadry zapasowej kawalerii dla Podlaskiej i Suwalskiej BK (analogicznie do formowanej ówcześnie w Łukowie kadry zapasowej dla Nowogródzkiej BK), tj. stałego powiązania szwadronów zapasowych jednej lub większej ilości brygad w garnizonie. Raport gen. Skuratowicza dla I wiceministra spraw wojskowych podkreślał, że w kompleksie koszarowym im. gen. Sowińskiego znajdowały się obiekty, które można przeznaczyć na potrzeby kadry zapasowej. Wedle jego oceny bez większych nakładów do wykorzystania nadawały się tu dwa budynki magazynowe, stanowiące składy materiału szwadronu zapasowego 2. pułku ułanów, dwa kolejne spełniałyby oczekiwania po odpowiedniej adaptacji. Jako pomieszczenia kwaterunkowe proponował wykorzystać obiekt obsadzony przez szwadron zapasowy 2. puł., zaś kolejny zaadaptować na potrzeby wartowni ${ }^{24}$. Wybuch wojny przekreślił jakiekolwiek dalsze działania.

Dyskusyjną kwestią pozostaje wierność odzwierciedlenia układu koszar na mapach. Mapa rosyjska z 1915 r. w skali 1:84 000 (arkusz XIX.14) pozostawia wiele do życzenia, uwzględnia bowiem 36 budynków, w tym zaledwie 11 z 15 baraków w północnej części obszaru koszar. Na niemieckiej mapie z 1915 r. z podziałką 1:25 000 (arkusz XIX-14-D), stanowiącej przeskalowaną i poprawioną wersję rosyjskiej, można doliczyć się 43 obiektów, w tym wszystkich baraków. Ze zrozumiałych względów polskie mapy Wojskowego Instytutu Geograficznego nie są szczególnie pomocne. Pomimo oznaczenia na nich kompleksów koszarowych, wewnętrzny układ budynków nie był ujawniany. Z kolei niemiecki Stadtplan von Bialystok, bazujący na mapie WIG w skali 1:100 000 (P36 S36), przeskalowany do podziałki 1:7 500 i po naniesieniu poprawek wydany w 1941 r., wyraźnie wskazuje 51 obiektów na terenie byłych koszar. Nie jestem w stanie stwierdzić, czy ostatnia mapa uwzględnia prawdopodobne sowieckie inwestycje budowlane z okresu 1939-1941.

23 CAW, Dep. Kaw. MSWojsk., I.300.30.55, Pismo L.dz. 414/MOB.36 I wiceministra SWojsk. gen. bryg. Regulskiego z 5 II 1937 r. w sprawie zbadania warunków koszarowych pod kątem OZKaw. W toku podróży komisja odwiedziła m.in. Łuków, Wołkowysk, Bielsk, Hrubieszów, Pińczów, Kielce, Płock, Dębicę i Tarnów. W efekcie jej prac w pierwszej kolejności utworzono kadrę zapasową kawalerii dla Nowogródzkiej BK w oparciu o koszary w Łukowie.

24 CAW, Dep. Kaw. MSWojsk., I.300.30.253, Pismo L.dz. 482/tj. z 22 III 1939 r. szefa Dep. Kaw. MSwojsk. gen. bryg. P. Skuratowicza do I wiceministra SWojsk. w sprawie inspekcji warunków wyszkolenia i zakwaterowania 10. puł. i 9. psk, s. 1-3. 
Koszary „włodzimierskie”, zaadaptowane i wykorzystywane przez Wojsko Polskie w latach 1920-1939, nie pozostawiły po sobie żadnych reliktów. Już w okresie II RP teren wokół kompleksu ulegał stopniowej parcelacji i zabudowie cywilnej. W obecnej chwili, bez sięgnięcia do fotograficznej dokumentacji lotniczej z 1944 r., nie można ocenić zniszczeń, jakim uległy zabudowania koszarowe $\mathrm{w}$ toku konfliktu niemiecko-sowieckiego, szczególnie podczas walk o Białystok w lipcu 1944 r. Można domniemywać, że były one niemałe, gdyż odbudowujące się po wojnie miasto w całości wchłonęło teren. Obecnie narys kompleksu jest widoczny jedynie w częściowo zachowanym układzie obrzeżnych ulic Wołodyjowskiego, Szpitalnej i Wojskowej, natomiast układ wewnętrzny uległ całkowitemu zatarciu ${ }^{25}$.

\section{b) Koszary im. marsz. J. Piłsudskiego}

Pierwsze oddziały rosyjskiej kawalerii armijnej ulokowano w Białymstoku na przełomie lat sześćdziesiątych i siedemdziesiątych XIX w. Był to wzmiankowany uprzednio 13 . Włodzimierski pułk. W $1875 \mathrm{r}$. w mieście rozkwaterowano, zapewne w prywatnych lokalach, elementy 4. DK: dowództwo i sztaby dywizji i podległej jej 1. BK, zaś w okolicznych wsiach 10. Jekaterynosławski pułk dragonów (do 1882 r. nosił nr 4.). Dwa lata później jednostki wyjechały na wojnę z Turcją, a opuszczone kwatery czasowo obsadził 18. batalion strzelców ${ }^{26}$. Nie jest do końca znana obsada garnizonu białostockiego przełomu lat siedemdziesiątych i osiemdziesiątych XIX w. Wiadomo, że w 1883 r. w mieście kwaterowały wymienione powyżej dowództwa związków taktycznych kawalerii (w lokalach przy ul. Aleksandrowskiej, ob. Warszawskiej) z częścią pododdziałów: 10. Jekaterynosławskim pdrag. oraz 7. i 8. bateriami artylerii konnej. Baterie zostały połączone w 4 . dywizjon artylerii konnej i dyslokowane w koszarach „artyleryjskich” (przy ob. ul. Artyleryjskiej i Dąbrowskiego). Cały garnizon stanowił niejako rzut odwodowy względem rozmieszczonych w pobliżu granicy innych jednostek dywizji (Suwałki - 6. Pawłogradzki pułk dragonów; Augustów, potem Szczuczyn - 4. pułk kozaków dońskich; Szczuczyn, potem Ostrołęa - 16. Głuchowski pdrag.; Łomża - 17. Wołyński pdrag.).

25 D. Gawryluk, Wptyw lokalizacji carskich koszar na strukture przestrzennq wybranych miast województwa podlaskiego, „TKAUiSK” 2015, t. XI, nr 1, s. 61, 63-64.

26 W Słonimie rozlokowano 4. Charkowski puł., w Wołkowysku 7. baterię artylerii konnej tejże brygady. R. Wróblewski, op. cit., s. 43; AOBHW, XI.3.5 (stara sygn.), A. Dobroński, op. cit., s. 4 . 
Według ustaleń Roberta Wróblewskiego, w pierwszej serii kształtujących się w Białymstoku kompleksów - nie licząc powstających od 1879 r. koszar „włodzimierskich" - znalazły się murowane pomieszczenia 64. Kazańskiego pp na północnych obrzeżach miasta (budowa 1884-1889), wznoszone od 1887 r. koszary 12. Mariupolskiego ${ }^{27}$ pdrag. (do 1882 r. nosił nr 4.) i od 1889 r. przesuniętego ze Słonima 11. Charkowskiego pdrag. (do 1882 r. funkcjonował jako 4. puł. ${ }^{28}$ ). Budowę kompleksu koszarowego dla ostatniej z wymienionych jednostek rozpoczęto z rocznym opóźnieniem, na południowo-zachodnim skraju miasta $\mathrm{w}$ rejonie wsi Słoboda przy szosie zambrowskiej. Podobnie jak w przypadku koszar „włodzimierskich”, dragoni 11. pułku budowę baraków rozpoczęli metodą gospodarczą. Kryzys ekonomiczny sprawił, że zamiast zlecania budowy prywatnym przedsiębiorcom i stosowania cegły jako podstawowego budulca, prace przeprowadzano rękami szeregowych. Powstało 8 drewnianych baraków mieszkalnych, 5 nowoczesnych stajni na 150 koni każda, szpital weterynaryjny z 50 stanowiskami, kryta ujeżdżalnia, kilka murowanych, jedno- lub dwukondygnacyjnych budynków sztabowych i mieszkalnych oraz magazyny. Jeszcze w czasie prac pułk ulokowano w prowizorycznych warunkach na placu budowy i stopniowo kwaterowano w oddawanych do użytku obiektach. Problemy z odpowiednimi pomieszczeniami dla sztabów nie znikły, niemal do wybuchu I wojny światowej dowództwa 4 . DK i jej brygad rozmieszczone były bowiem w wynajmowanych budynkach w mieście, kolejno w Domu "Moesa” przy ul. Staroszosejnej (św. Rocha), później w Domu "Sosnowskiej” przy ul. Botanicznej. Z kolei 10. Jekaterynosławski pdrag. (już jako 10. Nowotroicko-Jekaterynosławski pdrag.) oraz 4. pułk kozaków dońskich opuściły Białystok i okoliczne miejscowości i przeniosły się odpowiednio w $1883 \mathrm{r}$. do Obozu Potiomkina pod Grajewem oraz w 1888 r. do Augustowa, a następnie Szczuczyna ${ }^{29}$.

Nie istnieją pewne dane na temat ewentualnych zniszczeń kompleksu podczas wojen światowej i polsko-bolszewickiej, choć wiemy, że stopniowa dewastacja postępowała, czy to $\mathrm{z}$ powodu wandalizmu, czy przez brak odpowiedniej konserwacji drewnianych zabudowań. Zdecydowanie lepiej ten okres zniosły obiekty murowane: kryta ujeżdżalnia i część budynków

27 W literaturze przedmiotu bardzo często można spotkać błędną nazwę: „Mariampolski”.

28 Należy tu podkreślić, że po raz kolejny pułkom kawalerii zmieniono numery porządkowe, a niekiedy również formację: w grudniu 1907 r. 11. Charkowski pdrag. został zreorganizowany w 4. Charkowski puł., zaś 12. Mariupolski pdrag. rozpoczął funkcjonowanie jako 4. Mariupolski pułk huzarów.

29 R. Wróblewski, op. cit., s. 46-48, 50-51. 


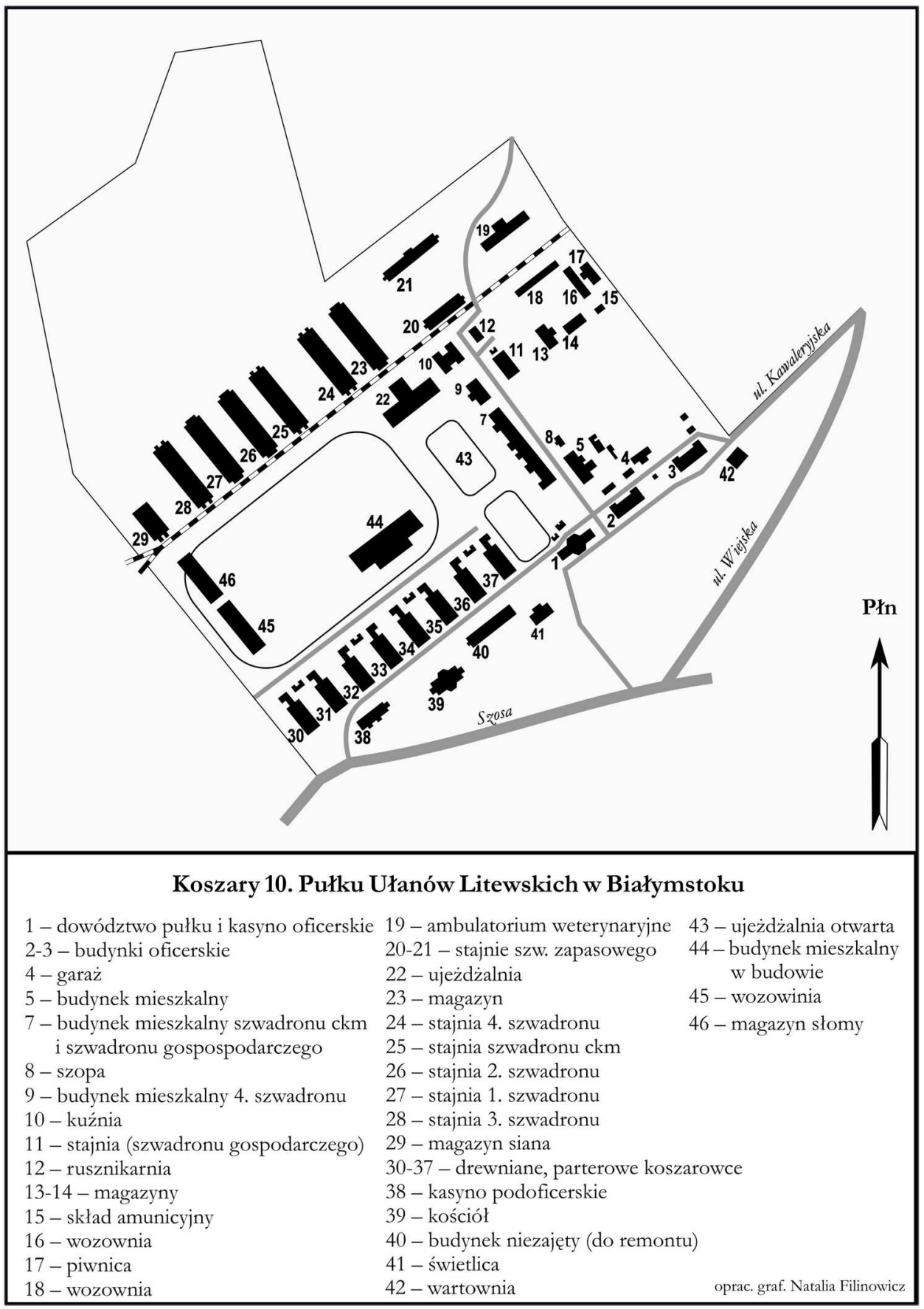


mieszkalnych kadry. Po przejęciu miasta przez Wojsko Polskie w 1919 r. czasowo stacjonował tu szwadron zapasowy 10. puł., zaś człon bojowy jednostki przebywał na froncie do września 1922 r. ${ }^{30}$ Pierwotnie planowano rozlokowanie 10. puł. w Grajewie, jednakże w 1921 r. zapadła decyzja o przeznaczeniu dlań porosyjskich koszar w Białymstoku. W celu przeprowadzenia wstępnych prac adaptacyjnych skierowano ponownie do Białegostoku szwadron zapasowy z Grajewa $\mathrm{w}$ trybie natychmiastowym. Pododdział podjął żmudne wysiłki w celu doprowadzenia obiektów do używalności. O konieczności włożenia dużego nakładu pracy świadczy fakt, że po przybyciu pułku do Białegostoku (II rzut w czerwcu, gros we wrześniu 1922 r.) zakwaterowano tu tylko część jednostki, kierując II dywizjon do porosyjskich koszar w Grajewie. Częściowo sytuację tę wymusiło zajmowanie szeregu obiektów tego kompleksu przez Rejonową Składnicę Intendencką. W samym kompleksie "charkowskim" prace nad stworzeniem możliwości kwaterunkowych odziedziczonych budynków kontynuowano metodą gospodarczą. Murowaną cerkiew (1909-1911) po przebudowie konsekrowano jako katolicki kościół koszarowy pw. św. Stanisława Biskupa Męczennika ${ }^{31}$. W 1924 r. skoncentrowano w Białymstoku cały pułk, zwalniając obiekty grajewskie dla 9. psk. Wniesiony w odbudowę nakład pracy spowodował, że w $1927 \mathrm{r}$. inspekcja uznała poziom zakwaterowania za dobry ${ }^{32}$. Należy dodać, że po przewrocie majowym utarła się nieoficjalna nazwa kompleksu: Koszary im. marszałka J. Piłsudskiego.

W kolejnych latach stan drewnianej zabudowy uległ pogorszeniu. W ocenie płk. dypl. L. Kmicica-Skrzyńskiego ponoszenie wszelkich nakładów na remont zbutwiałych, w niektórych przypadkach wręcz "walących się" budynków koszarowych i magazynowych mijało się z celem, a jedyną metodą usunięcia negatywnego wpływu fatalnego stanu obiektów i złych warunków sanitarno-bytowych na morale wojsk mogło być postawienie nowych budynków ${ }^{33}$. Tymczasem problemy gospodarcze państwa nie pozwalały na większe

30 A. Dobroński, K. Filipow, „Dziesiątacy” z Białegostoku. 10 Pułk Ułanów Litewskich, Białystok 1992, s. 14-16.

31 CAW, O I SG, I.303.3.154, Pismo O I SG L.dz. 5958/Mob. z 7 V 1921 r. - Organizacja i dyslokacja Brygad Jazdy - na czas pokoju; CAW, O I SG, I.303.3.154, Pismo O I SG L.dz. 6316/Mob. z 13 V 1921 r. - Plan rozlokowania Dywizji Piechoty i Brygad Jazdy w kraju z uwzględnieniem zmian zaszłych do dn. 25 IV, s. 5-8; R. Wróblewski, op. cit., s. 52-53.

32 A. J. Dąbrowski, Historia 10 Pułku Ułanów Litewskich, Londyn 1982, s. 176-177; J. S. Wojciechowski, op. cit.; B. Tomecka, Zespót koszarowy przy ul. Kawaleryjskiej. Studium historyczno-przestrzenne opracowane na zlecenie 18 Brygady Zmechanizowanej, Białystok 1995, passim.

33 CAW, Dep. Kaw. MSWojsk., I.300.30.132, Podlaska BK L.dz. 1115/I.Tjn.37 z 30 VI 1937 r. Sprawozdanie z wyszkolenia okresu zimowego 1936/37, s. 5. 
nakłady w tej dziedzinie. W kolejnych latach oddano co prawda do użytku kasyno podoficerskie (1931), drewniane ogrodzenie, drewniane pomieszczenia garażu na kuchnie polowe (szopy) i komorę gazową (1936), nie wyczerpywało to jednak potrzeb pułku. Na obecnym etapie badań niemożliwe jest stwierdzenie, czy winą za pogarszanie się warunków bytowych można obarczyć długoletniego dowódcę pułku płk. dypl. Witosława Porczyńskiego. Wydaje się, że przynajmniej w pewnym stopniu tak, gdyż brak należytych starań dowódcy pomimo jego kompetencji gospodarczych wykazała inspekcja Korpusu Kontrolerów w 1937 r. ${ }^{34}$ Również dowódca brygady zgłaszał zastrzeżenia $\mathrm{w}$ sprawie niezagospodarowania rozległego kompleksu, przy czym wykazywał zrozumienie dla faktu, że wykorzystywanie żołnierzy do prac odbijało się na procesie szkoleniowym. Podkreślał ponadto niekorzystne zakwaterowanie większości kadry zawodowej w wynajmowanych lokalach w mieście, a w samych koszarach m.in. brak ogrzewania i katastrofalny stan pomieszczeń stołówkowych, ustępów itd. ${ }^{35}$

O ile Departament Budownictwa MSWojsk. pozostawał głuchy na postulaty budowy obiektu mieszkalnego dla podoficerów zawodowych, to sukcesem zakończyły się zabiegi dowódcy brygady o wystawienie obiektu koszarowego dla szeregowych. W 1937 r. złożono odpowiednią dokumentację i na kolejny rok ministerstwo przyznało wysoki kredyt (175000 zł) na budowę murowanego obiektu koszarowego, zdolnego pomieścić dwa szwadrony $^{36}$. Inwestycja została rozpoczęta w 1938 r., lecz mimo powiększenia kredytu nie została ukończona do wybuchu wojny. Warto dodać, że była to druga co do wielkości inwestycja budowlana Dowództwa Okręgu Korpusu III w tym okresie, plasująca się tylko za rozbudową kompleksu 7. batalionu pancernego w Grodnie. W tymże roku dobudowano również drewnianą szopę-działownię do garażowania armat ppanc. wz. $36^{37}$. Wobec radykal-

34 CAW, Korpus Kontrolerów MSWojsk., I.300.16.82, Sprawozdanie Korpusu Kontrolerów nr 4852 za rok 1937/1938, s. 27-29, 46-48, 58, 61-62.

35 CAW, Departament Artylerii MSWojsk., I.300.34.147, Podlaska BK L.dz. 1801/I/tj.38 z 26 XI 1938 r. - Sprawozdanie z wyszkolenia za okres letni 1938 r., zał. 1/f - Warunki lokalne oddziałów.

36 CAW, Dep. Kaw. MSWojsk., I.300.30.132, Podlaska BK L.dz. 1115/I.Tjn.37 z 30 VI 1937 r. Sprawozdanie z wyszkolenia okresu zimowego 1936/37, s. 5-7; CAW, Dep. Kaw. MSWojsk., I.300.30.132, Pismo L. 1151/tjn. z 6 VII 1937 r. szefa Dep. Budownictwa MSWojsk. w sprawie braków w budownictwie w Podlaskiej BK; CAW, O I SG, I.303.3.647, Zestawienie kwot preliminowanych w budżecie "N" MSWojsk na okres 1938/39.

37 CAW, O I SG, I.303.3.647, Pismo DDO MSWojsk. L.dz. 2439/Org.Tjn z 30 III 1938 r. do szefa SG w sprawie realizacji zamierzeń budowlanych na rok 1938-1939; CAW, Oddziały Kawalerii, I.321.10.15. Rozkaz dzienny 10. puł. nr 204/38 z 4 X 1938 r., s. 2; J. S. Wojciechowski, op. cit., s. 172-175. 
nego ograniczenia środków na konserwację i remont budynków w ostatnich latach przed wojną i koncentracji wydatków budowlanych na finansowaniu nowych, wybranych obiektów dla rozwijanych broni technicznych ${ }^{38}$, budowa koszarowca w kompleksie 10. pułku wskazuje, jak fatalny był stan drewnianych obiektów na terenie koszar im. Piłsudskiego.

Wspomniana uprzednio wizytacja szefa Departamentu Kawalerii gen. bryg. P. Skuratowicza nie ominęła również kwater 10. puł. W sprawozdaniu generał opisał znaczną liczbę niezagospodarowanych obiektów, które zamierzał użytkować poprzez rozmieszczenie tu szwadronu koni zapasowych. Ponadto postulował wykorzystanie dwóch najlepiej zachowanych drewnianych baraków (z tego jeden był już obsadzony przez szwadron zapasowy 10. puł.), a także użytkowanych przez ten pododdział dwóch stajni na 112 stanowisk, oraz wykorzystanie około 200 wolnych stanowisk w stajniach pułku i zagospodarowanie licznych, wolnych magazynów ${ }^{39}$. Można domniemywać, że gen. Skuratowicz odnotował jedynie fakt istnienia obiektów, nie zaś stan ich zachowania. Potwierdzeniem mogą być inspekcje wykonywane przez oficerów Korpusu Kontrolerów, wskazujące tragiczny stan zabudowań magazynowych ${ }^{40}$.

W okresie okupacji niemieckiej lat 1941-1944 na terenie koszar czasowo funkcjonował obóz dla sowieckich jeńców, a po opanowaniu Białegostoku przez Armię Czerwoną - obóz dla wziętych do niewoli Niemców. Do wiedzy o zabudowie i budulcu poszczególnych obiektów w kompleksie wiele wnosi szkic, wykonany w 1944 r. przez wywiad Armii Krajowej na potrzeby planowania akcji „Burza”. Wynika z niego m.in., że magazyn oznaczony na załączonej mapie numerem 23 był murowaną stajnią. Ogólnie spośród 44 obiektów 12 zostało oznaczonych jako murowane. Ponadto ustalono, iż budynki z numerami 4 (garaż) i 28 (stajnia drewniana) uległy spaleniu

38 CAW, O I SG, I.303.3.799, DOK III Sztab, Samodzielny Referat Ogólny L. 2188/Og.tjn.37, Sprawozdanie z przebiegu odprawy dowódców wielkich jednostek i dowódców formacyj pozadywizyjnych w Sztabie D.O.K. III w dniu 29 kwietnia 1937 r., Grodno, maj 1937 r., s. 2-13; CAW, DOK III/42, Rozkaz Tajny Zewnętrzny DOK III nr 20, Grodno, dn. 22 V 1939 r., s. 10.

39 CAW, Dep. Kaw. MSWojsk., I.300.30.253, Pismo L.dz. 482/tj. z 22 III 1939 r. szefa Dep. Kaw. MSwojsk. gen. bryg. P. Skuratowicza do I wiceministra SWojsk. w sprawie inspekcji warunków wyszkolenia i zakwaterowania 10. puł. i 9. psk, s. 1-3.

40 CAW, Dep. Kaw. MSWojsk., I.300.30.253, Pismo L.dz. 482/tj. z 22 III 1939 r. szefa Dep. Kaw. MSwojsk. gen. bryg. P. Skuratowicza do I wiceministra SWojsk. w sprawie inspekcji warunków wyszkolenia i zakwaterowania 10. puł. i 9. psk, s. 1-3. 
podczas wojny ${ }^{41}$. Po jej zakończeniu koszary mieściły jednostkę Korpusu Bezpieczeństwa Wewnętrznego (od 1947 r.), a później formacje Wojsk Obrony Wewnętrznej.

Obecnie kompleks użytkuje Wojsko Polskie, co w pewnym stopniu chroni go przed losem koszar im. gen. Sowińskiego. Warto podkreślić, że spośród co najmniej 44 budynków istniejących w 1939 r., znaczna część zachowuje, przynajmniej zewnętrznie, wygląd z epoki. Oczywiście, zaszły bardzo poważne zmiany zabudowy, np. z ośmiu baraków mieszkalnych, których fatalny stan zachowania opisałem powyżej, po dziś dzień uchowały się tylko dwa, miejsce pozostałych zajmuje plac apelowy, kilkakrotnie mniejszy i przesunięty względem bardzo obszernego sprzed 1939 r. Prace nad budynkiem koszarowym przerwane w 1939 r., prawdopodobnie zakończone zostały w czasie okupacji niemieckiej, a obiekt ten pozostaje w użytkowaniu do dziś. Według Szymona Kucharskiego jest to prawdopodobnie jedyny kawaleryjski budynek z okresu II RP, zachowany w dzisiejszych granicach państwa. Ocalała również świątynia, odrestaurowana po 1945 r., lecz po kilku latach zlikwidowana jako parafia wojskowa. W 1990 r. została wyłączona poza obręb kompleksu i pełni dziś rolę samodzielnego kościoła parafialnego ${ }^{42}$.

\section{c) Koszary im. gen. J. Bema}

W roku 1887, trzy lata przed wzniesieniem koszar "charkowskich", Rosjanie wykupili grunta majątku Bażantarnia na zachodnim skraju Białegostoku i rozpoczęli wznoszenie koszar kawaleryjskich dla 12. Mariupolskiego pdrag. (od grudnia 1907 r. 4. Mariupolski pułk huzarów) z 4. DK. Ze względu na narastający kryzys budowa uległa wyhamowaniu. Niewykluczone, że było to powodem opóźnienia relokacji pułku do Białegostoku i zakwaterowania w nieukończonym jeszcze kompleksie w 1892 lub 1893 r. Sam obszar przeznaczony pod koszary był rozległy; centrum zajmował obszerny plac apelowy, wokół którego budowano murowane budynki sztabu, bloki mieszkaniowe dla kadry oraz trzy duże, nowoczesne, dwukondygnacyjne koszarowce, każdy przeznaczony dla dwóch szwadronów, z użytkowym

41 M. Zwolski, Śladami zbrodni okresu stalinowskiego w województwie białostockim, Białystok 2013, s. 24-25.

42 S. Kucharski, Koszary, [w:] Odznaki kawalerii, t. 22: 10 pułk ułanów (seria: Wielka Księga Kawalerii Polskiej 1918-1939), Warszawa 2019, s. 32-34; D. Gawryluk, Wpływ lokalizacji..., s. 63. 
przyziemiem magazynowym. Podkreślić należy wysoki standard warunków zakwaterowania i zapewnienie odpowiednich warunków sanitarnych: 12 dwunastoosobowych izb żołnierskich każdego piętra uzupełniało pięć lokali służbowych i dwa sanitariaty. Ponadto zbudowano pięć stajni (drewniane z ceglanymi filarami), mogących pomieścić po 150 koni, stajnię weterynaryjną z 50 stanowiskami, krytą ujeżdżalnię i szereg innych obiektów. W kompleksie ulokowano ponadto 10 murowano-drewnianych magazynów lokalnego Zarządu Intendentury, a w 1897 r. wyświęcono drewnianą cerkiew ${ }^{43}$. Według niepotwierdzonych informacji dyslokowana tu była czasowo również bliżej nieznana jednostka artylerii polowej ${ }^{44}$.

Poziom zniszczeń w koszarach „mariupolskich” podczas działań wojennych lat 1914-1920 był najmniejszy wśród białostockich kompleksów. Wpływ na to miało wykorzystanie cegły jako budulca, a także nowoczesność założenia, które było wykorzystywane przez niemieckie oddziały okupacyjne. Niemcy przeprowadzili tu nawet dodatkowe inwestycje i modyfikacje budynków oraz wybudowali niewielką strzelnicę. W czasie przejścia frontu przez Białystok w 1920 r. koszary, podobnie jak inne białostockie obiekty wojskowe, zostały ograbione z ruchomości przez ludność cywilną ${ }^{45}$. W $1921 \mathrm{r}$. kompleks został przeznaczony na stałe miejsce dyslokacji 8. dywizjonu artylerii konnej (później funkcjonował jako 9., a od 1927 r. jako 14. dak). Przeniesienie oddziału z Przeworska przeprowadzono latem 1921 r. i połączono $\mathrm{z}$ nadaniem (nieoficjalnie) imienia patrona - gen. Józefa Bema. W tym okresie $\mathrm{w}$ obiekcie rozmieszczono również baterię zapasową 18. pułku artylerii polowej $^{46}$.

W pierwszych latach stacjonowania tu Wojska Polskiego nie istniała konieczność poważniejszych inwestycji, rozbiórce poddano jedynie cerkiew. W 1929 r. koszary przeszły proces adaptacyjny wg projektu inż. arch. J. Morawskiego, przystosowujący jeden z budynków na potrzeby Domu Oficerskiego (budynek Funduszu Kwaterunku Wojskowego ${ }^{47}$ ), w którym utworzono 18 mieszkań (inspekcja Korpusu Kontrolerów z 1935 r. wskazała, iż zajętych było tylko 16). W należącym do Skarbu Państwa budynku

43 R. Wróblewski, op. cit., s. 46-48, 50-53; AOBHW, XI.3.5 (stara sygn.), A. Dobroński, op. cit., s. 4.

44 K. Szczepański, Wspomnienia o 14 dywizjonie artylerii konnej, Białystok 2004.

45 H. Mościcki, op. cit., s. 172.

46 CAW, O I SG, I.303.3.154, Pismo O I SG L.dz. 6316/Mob. z 13 V 1921 r. - Plan rozlokowania Dywizji Piechoty i Brygad Jazdy w kraju z uwzględnieniem zmian zaszłych do dn. 25 IV, s. $5-8$.

47 J. Chęciński, op. cit., s. 148 i nast. 


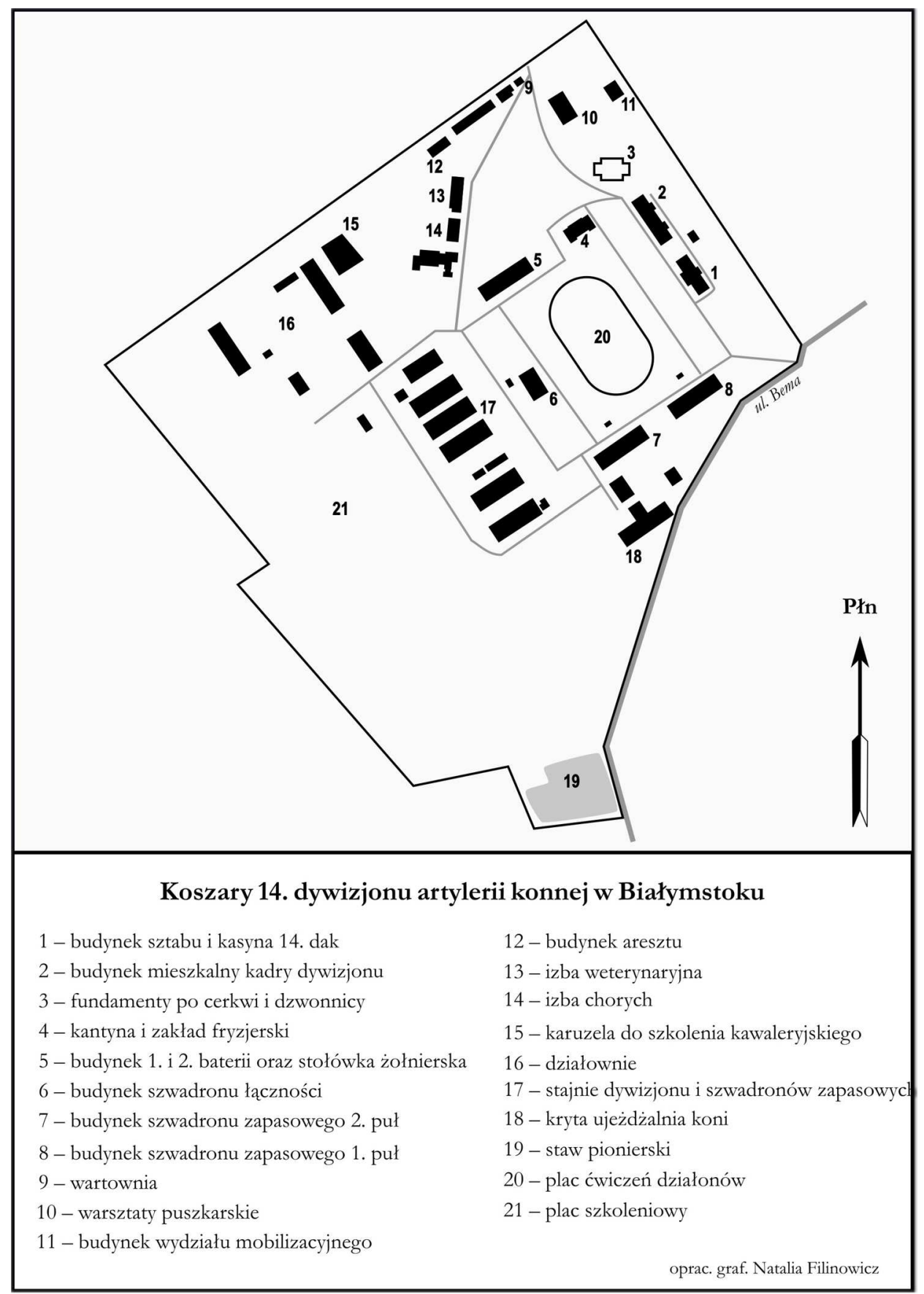


mieszkalnym znajdowało się z kolei sześć mieszkań, z czego tylko połowa była $\mathrm{w}$ użytku ${ }^{48}$. Wejście do budynku sztabu zdobiło charakterystyczne założenie architektoniczne z lufami armatnimi; wewnątrz mieściło się dowództwo dywizjonu i kasyno oficerskie, zaś willa dowódcy z ogrodem znajdowała się już poza ogrodzeniem. W kompleksie poza 14. dak stacjonowały również: 1. szwadron pionierów, ćwiczący w oparciu o znajdujący się w północnej części kompleksu staw pionierski, szwadrony zapasowe 1. puł. z Augustowa oraz 9. psk z Grajewa i Osowca, przy czym te ostatnie podlegały pod względem rozkazodawczym, dyscyplinarnym, intendenckim i taborowym pod odnośne pułki, zaś w kwestiach materiałowych - dowódcy 14. dak. Ostatnią inwestycją przed wybuchem wojny była oddana do użytku w 1939 r. parterowa wartownia przy bramie południowej (ul. Bema, obecnie poważnie przebudowana) ${ }^{49}$. W końcowym okresie istnienia II RP remontu wymagały stajnie, instalacja elektryczna, studnie (jedynie 4 z 13 posiadały sprawne pompy) i dachy niektórych budynków (m.in. magazynu słomy i siana, w którym corocznie tracono z powodu wilgoci ok. 10\% zapasów), sieć kanalizacyjna oraz ambulanse medyczny i weterynaryjny. Zabrakło środków na postawienie garaży, choć posiadano większość materiałów budowlanych ${ }^{50}$. Ta analiza wskazuje, że nie wsparto na czas zarządu koszar odpowiednimi kwotami na konserwację i drobne remonty, w efekcie poszczególne obiekty niszczały, a przywrócenie ich do odpowiedniego stanu wymagało zdecydowanie większych nakładów finansowych. Pewnym usprawiedliwieniem może być fakt, że w ostatnich latach przed wojną poważnie ograniczono wydatki na konserwację i fundusz remontowy, wręcz zakazano składania wniosków o dodatkowe środki, a niezbędne prace nakazano wykonywać metodą gospodarczą ${ }^{51}$.

48 CAW, Korpus Kontrolerów MSWojsk., I.300.16.526, Sprawozdanie L.27/Sz./35 z 25 VI 1935 r., z kontroli w 14. dak, s. 12-19.

49 CAW, DOK III/35, Załącznik do Rozkazu tajnego nr 7/36, Grodno, s. 1; AIPMS, B.I.17/A/1,

L. Kmicic-Skrzyński, Charakterystyka garnizonów, s. 2. K. Szczepański, op. cit., s. 18, 20;

B. Tomecka, Białystok. Zespół koszarowy..., s. 12-22.

50 CAW, Korpus Kontrolerów MSWojsk., I.300.16.526, Sprawozdanie L.27/Sz./35 z 25 VI 1935 r. z kontroli w 14. dak, s. 11-19; CAW, Dep. Art. MSWojsk., I.300.34.147, 14. dak L.dz. 861/tjn. z 19 X 1938 r. - Sprawozdanie z wyszkolenia za okres 1938 roku, zał. 4 Dział zakwaterowania, passim.

51 CAW, O I SG, I.303.3.799, DOK III Samodzielny Referat Ogólny L. 2188/Og.tjn.37, Sprawozdanie z przebiegu odprawy dowódców wielkich jednostek i dowódców formacyj pozadywizyjnych w Sztabie D.O.K. III w dniu 29 kwietnia 1937 r., Grodno, maj 1937 r., s. 2-13; DOK III/42, Rozkaz Tajny Zewnętrzny DOK III nr 20, Grodno, dn. 22 V 1939 r., s. 10. 
W połowie lat trzydziestych, gdy powyższe niedopatrzenia nie zostały jeszcze dostatecznie nagłośnione, powszechnie uważano stan koszar im. gen. J. Bema za bardzo dobry, pojemność wystarczającą, a poprawić go mogło tylko przeniesienie 1. szwadronu pionierów do Ostrołęki, planowane od 1937 r., a zrealizowane ostatecznie wiosną następnego roku. Mimo to przed 1937 r. szkoły podoficerskie ckm BK „Białystok” organizowano w koszarach 1. puł. w Augustowie, a później - przy 5. puł. w Ostrołęce ${ }^{52}$. Dopiero w 1939 r. Podlaskiej BK zlecono zadanie zorganizowania szkół podoficerskich ckm dla Wileńskiej i Nowogródzkiej BK, które zamierzano ulokować właśnie w koszarach im. gen. Bema, zaś szkoły plutonów ppanc. tych brygad oraz własnej - w koszarach II dywizjonu 9. psk w Osowcu ${ }^{53}$. W tymże roku szef Departamentu Kawalerii MSWojsk., wizytujący w marcu 1939 r. również koszary im. gen. Bema, jako miejsce ulokowania kadry zapasowej wskazał m.in.: budynek mieszkalny zajęty przez szkołę podoficerską ckm 14. dak, pół budynku mieszkalnego zajętego przez szwadron zapasowy 9. psk, stajnię ze 140 stanowiskami (również podległą szkole ckm) oraz identyczną stajnię użytkowaną przez szwadrony zapasowe 1. puł. i 9. psk. Gen. Skuratowicz przychylił się także do wniosku komendanta koszar z ubiegłego roku i polecił opracowanie preliminarza budżetowego na budowę nowej kuchni ${ }^{54}$. O ile jakość koszar ogólnie można uznać za zadowalającą, to plac ćwiczeń

52 CAW, Dep. Kaw. MSWojsk., I.300.30.141, Pismo szefa Dep. Kaw. MSWojsk. L.dz.105/ Studj.tjn. wg rozdzielnika z lutego 1933 r. w sprawie organizacji szkół podoficerskich ckm; CAW, Dep. Kaw. MSWojsk. I.300.30.141, Dowództwo BK „Białystok” L.dz. 5/Tj. z 21 I 1935 r. - Rozkaz organizacyjny dla szkoły podoficerskiej ckm na rok 1935; CAW, Dep. Kaw. MSWojsk. I.300.30.141, Rozkaz szefa Dep. Kaw. MSWojsk. L.dz. 1609/tj. z 2 I 1936 r. wg rozdzielnika w sprawie organizacji szkół podoficerskich ckm na rok 1936; CAW, Dep. Kaw. MSWojsk. I.300.30.141, Pismo L.dz. 2117/tj.36 z 11 I 1937 r. szefa Dep. Kaw. MSWojsk. wg rozdzielnika w sprawie organizacji szkół podoficerskich ckm na rok 1937, tab. nr 1; CAW, Dep. Kaw. MSWojsk., I.300.30.131, Podlaska BK L.dz. 1920/I.tj.37 z 20 XI 1937 r. Sprawozdanie z wyszkolenia za okres letni 1937 r., zał. 9 - Przebieg szkolenia w szkole podoficerskiej ckm.

53 CAW, Dep. Kaw. MSWojsk., I.300.30.128, Podlaska BK L.dz. 1/I/tj.39 z 2 I 1939 r. - Rozkaz organizacyjny dla XII kursu szkoły podofic. c.k.m. i samodzielnego plutonu szkolnego działonowych armatek ppanc. $37 \mathrm{~mm}$ na r. 1939, s. 1-4, 6-9, załącznik 2 - Zarządzenie wykonawcze dla oddziałów Podlaskiej BK, s. 1.

54 CAW, Dep. Kaw. MSWojsk., I.300.30.253, Pismo L.dz. 482/tj. z 22 III 1939 r. szefa Dep. Kaw. MSwojsk. gen. bryg. P. Skuratowicza do I wiceministra SWojsk. w sprawie inspekcji warunków wyszkolenia i zakwaterowania 10. puł. i 9. psk, s. 1-3; CAW, Dep. Kaw. MSWojsk. I.300.30.141, Dep. Kaw. MSWojsk. L.dz. 2500/tj. z 21 XII 1938 r. wg rozdzielnika w sprawie uruchomienia podoficerskich szkół ckm w roku 1939; CAW, Dep. Kaw. MSWojsk. I.300.30.141, Pismo dowódcy Podlaskiej BK L.dz. 97/tj./I.39 z 17 I 1939 r. do szefa Dep. Kaw. MSWojsk. w sprawie uruchomienia dowódcy plutonu szkolnego dział ppanc. w 1939. 
- nadający się w zupełności do musztry szwadronów kawalerii - okazał się zbyt mały dla artylerii konnej, nawet jeśli mowa tylko o szkoleniu podstawowym kanonierów w manewrowaniu baterii zaprzęgniętej ${ }^{55}$.

Nie wiadomo, w jakim stanie koszary 14. dak przetrwały II wojnę światową. Można domniemywać, że stan zachowania był dobry, znaczna część ocalałych budynków została bowiem w drugiej połowie 1944 r. przejęta przez „ludowe” Wojsko Polskie, a następnie przez Wojska Ochrony Pogranicza. Od 1990 r. w koszarach mieści się Podlaski Oddział Straży Granicznej. Kompleks zachował znaczną czytelność, zarówno dzięki użytkowaniu większości budynków murowanych, jak i utrzymanemu układowi ulic okalających kompleks ${ }^{56}$.

\section{d) Strzelnice i place ćwiczeń garnizonu Białystok}

Oddziały garnizonu białostockiego dysponowały własną infrastrukturą szkoleniową w postaci przykoszarowych strzelnic. Niestety, relikty żadnej z nich nie zachowały się do czasów współczesnych, a ich użyteczność możliwa jest do odtworzenia wyłącznie na podstawie materiałów archiwalnych i kartograficznych.

Wspomniano wyżej, że na terenie koszar im. gen. J. Sowińskiego w latach trzydziestych zbudowano 50-metrową strzelnicę pistoletową. Charakter stacjonujących w tym kompleksie elementów Podlaskiej BK nie wymuszał konieczności posiadania strzelnicy karabinowej. Na północ od koszar im. marsz. J. Piłsudskiego znajdowała się dwuosiowa strzelnica broni ręcznej, jednakże nadawała się ona wyłącznie do strzelań szkolnych, ponadto $\mathrm{z}$ racji braku zadaszeń nie umożliwiała prowadzenia zajęć $\mathrm{w}$ każdych warunkach pogodowych, posiadała niską przepustowość, a ograniczona długość linii ognia (do $300 \mathrm{~m}$ ) wykluczała przeprowadzenie wszystkich punktów programów szkoleniowych. W 1939 r. zamierzano przeprowadzić wykup gruntów i rozszerzenie obiektu do czterech osi, jednakże zamierzenia nie zostały zrealizowane do wybuchu wojny ${ }^{57}$. Obecnie nieistniejący obiekt jest mylnie

55 CAW, Dep. Art. MSWojsk., I.300.34.147, 14. dak L.dz. 861/tjn. z 19 X 1938 r. - Sprawozdanie z wyszkolenia za okres $1938 \mathrm{r}$.

D. Gawryluk, Wptyw lokalizacji..., s. 61, 63.

57 CAW, Dep. Art. MSWojsk., I.300.34.147, Podlaska BK L.dz. 1801/I/tj.38 z 26 XI 1938 r. Sprawozdanie z wyszkolenia za okres letni 1938 r., zał. 1/f - Warunki lokalne oddziałów; AIPMS, B.I.17/A/1, L. Kmicic-Skrzyński, Charakterystyka garnizonów, s. 2; E. Kula, Gdzie mieszkali "dziesiątacy”, s. 4; CAW, Korpus Kontrolerów MSWojsk., I.300.16.82, Sprawozdanie Korpusu Kontrolerów nr 4852 za rok 1937/1938, s. 58-62. 
utożsamiany z nieczynną już, powojenną strzelnicą pistoletową na południe od koszar.

Ponawiane wnioski o budowę odpowiednich strzelnic (w tym wieloosiowych o długości linii ognia do $400 \mathrm{~m}$ ) i placów ćwiczeń w pobliżu stałych miejsc dyslokacji oddziałów rozbijały się o brak środków i inercję odnośnych instytucji. Przełożeni Podlaskiej BK mieli świadomość trudności infrastrukturalnych i problemów w materii wyszkolenia, lecz obietnice budowy odpowiednich strzelnic i zapewnienia placów ćwiczeń nieustannie odkładano w bliżej niesprecyzowaną przyszłość. Dowódca OK III Grodno w 1937 r. zapowiedział dowódcom wielkich jednostek stacjonujących na podległym mu terytorium, że projekt budowy obiektów strzeleckich został przedłożony odnośnemu ministrowi, i w wypadku akceptacji, wszystkie garnizony mogły spodziewać się inwestycji w tej dziedzinie w przeciągu kilku lat ${ }^{58}$.

Pozbawione strzelnic z prawdziwego zdarzenia oddziały Podlaskiej BK garnizonu Białystok musiały przeprowadzać strzelania szkolno-bojowe i bojowe jedynie podczas koncentracji letniej, zazwyczaj korzystając ze strzelnicy Sośnia koło Osowca. Kumulacja strzelań w krótkim okresie letnim wpływała negatywnie na wyszkolenie żołnierzy. Jeszcze gorzej przedstawiało się wyszkolenie ogniowe artylerii konnej. Dla przeprowadzenia strzelań 14. dak musiał przemieszczać się na odległe poligony, zazwyczaj do Czerwonego Boru, Pohulanki pod Wilnem lub Obozu Leśna. Prawdopodobnie tylko jeden raz w II RP, i to w okresie zimowym, dywizjon przeprowadził ograniczone szkolenie strzeleckie $\mathrm{w}$ pobliżu garnizonu, kilka km na północ od Wasilkowa ${ }^{59}$. Latem 1939 r., w związku z narastającym zagrożeniem wojennym, jednostki Wojska Polskiego zostały przywiązane ściślej do miejsc stałej dyslokacji. Oddziały Podlaskiej BK musiały przeprowadzić zgrupowania ćwiczebne w rejonie garnizonów i na miejscu wykonać strzelania ostre pododdziałami niższego szczebla: 5. puł. na strzelnicy w Dylewie lub w Czerwonym Borze, 9. psk na strzelnicy Sośnia pod Osowcem, zaś 10. puł. na strzel-

58 CAW, Dep. Kaw MSWojsk., I.300.30.37, Spostrzeżenia dowódcy BK Białystok z organizacji i wyszkolenia brygady za rok 1934, brak dziennika i daty, s. 1-4; CAW, Dep. Kaw. MSWojsk., I.300.30.38, Część B. Odpowiedzi na zapytania i wnioski nadesłane w związku z odprawą, których udzieli szef Dep. Kaw. na odprawie ogólnej, s. 5; CAW, Dep. Kaw. MSWojsk., I.300.30.38, Pismo L.dz. 7400/I.Og.Tjn.37 DDO MSWojsk. - Odpowiedzi na zapytania dowódców okręgów korpusów z okazji odprawy w październiku 1937 r., cz. II, s. 88; CAW, O I SG, I.303.3.799, DOK III Samodzielny Referat Ogólny L. 2188/Og.tjn.37, Sprawozdanie z przebiegu odprawy dowódców wielkich jednostek i dowódców formacyj pozadywizyjnych w Sztabie D.O.K. III w dniu 29 kwietnia 1937 r., Grodno, maj 1937 r., s. 19.

59 AIPMS, B.I.17/A/1, L. Kmicic-Skrzyński, Charakterystyka garnizonów, s. 2. 
nicy Święta Woda pod Białymstokiem ${ }^{60}$. O tym ostatnim obiekcie w obecnej chwili nic nie wiadomo, nie udało się ustalić jego lokalizacji ani śladów $\mathrm{w}$ terenie.

Pod rozkazami komendanta białostockiego garnizonu znajdował się plac ćwiczeń Pietrasze, stosunkowo duży, o bogatej rzeźbie terenu i urozmaiconej szacie roślinnej, nadający się do ćwiczeń pododdziałów. Został utworzony w końcu XIX w. na terenie folwarku Pietrasze jako stały obóz letni na potrzeby rosyjskiej 16 . DP. Teren był wzbogacony szeregiem prowizorycznych budynków drewnianych, szkolnymi umocnieniami polowymi, a także nowoczesną, wieloosiową strzelnicą ${ }^{61}$. W 1920 r. obóz został przejęty przez Wojsko Polskie i użytkowany zgodnie z pierwotnym przeznaczeniem. Z racji bliskości do zespołu koszarowego zajmowanego przez 42. pp, jednostka ta pozostawała głównym użytkownikiem obiektu; inne oddziały garnizonu wykorzystywały ten obszar w dużo mniejszym stopniu. Nie udało się wyjaśnić, czy istotnie od 1929 r. jednostką administrującą garnizonowym placem ćwiczeń „Pietrasze” został 10. puł. ${ }^{62}$, co z perspektywy rozmieszczenia oddziałów garnizonu wydaje się nielogiczne. Należy również podkreślić, że użyteczność obszaru z czasem spadała, głównie za sprawą znacznej redukcji jego powierzchni w wyniku inwestycji cywilnych. Wiadomo, że w 1939 r. obejmował on obszar 473 ha $^{63}$. Za mało prawdopodobne należy uznać, iż tak ograniczonym terenem zadowoliłoby się dowództwo rosyjskiej dywizji w końcu XIX w. Co ciekawe, przynajmniej do przełomu lat 20. i 30. wykonywano na nim również część strzelań szkolno-bojowych, jednak praktyki tej zaniechano po przypadkach postrzeleń osób cywilnych. Po tym fakcie degradacja placu ćwiczeń postępowała jeszcze szybciej.

W związku z powyższym jednostki garnizonu zmuszone były do wykorzystywania strzelnic przykoszarowych $\mathrm{i}-\mathrm{w}$ minimalnym zakresie - garnizonowego placu ćwiczeń jedynie do strzelań szkolnych. Wszelkie interwencje komendanta garnizonu u przełożonych rozbijały się o brak środków na wykup gruntów i budowę odpowiednich obiektów. Przynajmniej od 1932 r. postulował on wykup (wedle jego rozeznania za kwotę 237000 zł) lub dzierżawę obszaru w pobliżu wsi Karakule i Grabówka o powierzchni 630 ha, przy

60 CAW, Dep. Kaw. MSWojsk., I.300.30.147, Dowództwo BK „Białystok” L.dz. 1154/I/tj.39 z 26 VI 1939 r. - Obóz letni i koncentracja - sposób przeprowadzenia.

61 R. Wróblewski, op. cit., s. 50-51.

62 J. S. Wojciechowski, op. cit., s. 172.

63 CAW, Dep. Kaw. MSWojsk., I.300.30.253, Pismo L.dz. 482/tj. z 22 III 1939 r. szefa Dep. Kaw. MSwojsk. gen. bryg. P. Skuratowicza do I wiceministra SWojsk. w sprawie inspekcji warunków wyszkolenia i zakwaterowania 10. puł. i 9. psk, s. 1-3. 
czym część tego terenu była już czasowo użytkowana; niejasna pozostaje jednak podstawa prawna tych działań. Improwizowana strzelnica szkolno-bojowa pod Grabówką z każdym rokiem traciła swoją użyteczność z powodu postępującej parcelacji i zabudowywania obszaru. Niedostatki szkoleniowe dowódca Podlaskiej BK próbował redukować poprzez improwizacje i doraźne inicjatywy. Na przykład w 1935 r. nakazał przeprowadzenie ćwiczeń taktycznych na Pietraszach mniejszymi pododdziałami. Do wybuchu wojny starania o pozyskanie terenu ćwiczebnego dla brygady, jak również wysiłki o zapewnienie przykoszarowych placów dla 10. puł., 14. dak i brygadowego szwadronu pionierów zakończyły się niepowodzeniem ${ }^{64}$.

Wskazane problemy powodowały, że cierpiał poziom wyszkolenia strzeleckiego oraz zgrania pododdziałów Podlaskiej BK. Dowódca brygady organizował ćwiczenia dwustronne lub szkolno-bojowe w różnych, nieraz odległych lokacjach. Na przykład w 1932 r. część oddziałów ćwiczyła samodzielnie, m.in. elementy garnizonu białostockiego na Pietraszach wraz z 42. pp i Przysposobieniem Wojskowym Konnym, zaś na strzelania szkolno-bojowe 10. puł. musiał udać się aż do Grodna, by skorzystać z Obozu Ćwiczeń 29. DP „Rumlówka”. Z kolei w 1935 r. 9. psk i oddziały garnizonu białostockiego przed koncentracją letnią odbyły strzelania szkolno-bojowe tylko do szczebla plutonu, wobec czego potrzebowały dodatkowego zgrupowania (przedobozia) dla przeprowadzenia ćwiczeń bojowych, strzelań szkolno-bojowych, nauki pływania itd. ${ }^{65} \mathrm{~W} 1937$ r. 5. puł. i 9. psk zdołały przeprowadzić strzelenia szkolne i szkolno-bojowe przed koncentracją (odpowiednio pod Dylewem i Osowcem), zaś oddziały białostockie przybyły na koncentrację brygady bez przeprowadzonych strzelań w specjalnościach strzelców wyborowych i karabinów maszynowych. Muszę dodać, że w takich sytuacjach zgrupowania przed okresem letniego sprawdzianu na ogół udawało się zorganizować, niemniej niosło to ze sobą niekorzystne skoncentrowanie ćwiczeń strzeleckich w krótkim czasie, odbijające się na negatywnych rezultatach szkolenia ${ }^{66}$.

64 CAW, Dep. Kaw. MSWojsk., I.300.30.131, Podlaska BK L.dz. 1920/I.tj.37 z 20 XI 1937 r. Sprawozdanie z wyszkolenia za okres letni 1937 r., zał. 3, 7; CAW, Dep. Kaw. MSWojsk., I.300.30.131, Wyciąg z dezyderatów dowódców wielkich jednostek na odprawę. Sprawy Dep. Kaw. MSWojsk., Wniosek dowódcy BK „Białystok”.

65 CAW, Dep. Kaw. MSWojsk., I.300.30.147, Dowództwo BK „Białystok” L.dz. 565/tj.32 z 10 X 1932 r. - Sprawozdanie z okresu przedkoncentracyjnego i koncentracji BK „Białystok” za 1932 r., s. 1; CAW, Dep. Kaw. MSWojsk., I.300.30.147, Pismo dowódcy BK „Białystok” L.dz. 22/tj. z 14 I 1935 r. do szefa Dep. Kaw. MSWojsk. w sprawie organizacji przedobozia BK w 1935 r., s. 1.

66 CAW, Dep. Kaw. MSWojsk., I.300.30.131, Dowództwo Podlaskiej BK L.dz. 1920/I.Tjn.37 z 20 XI 1937 r. - Czynniki organizacyjno-materialne wpływające na tok szkolenia i do- 


\section{Zespoły koszarowe i ćwiczebne garnizonu Ostrołęka}

\section{a) Kompleks koszarowy Wojciechowice}

Ostrołęka w okresie II Rzeczpospolitej była siedzibą powiatu, przy czym część jednostki administracyjnej na północ od Narwi uznawano za niezamożną, pozbawioną wartościowych zasobów przydatnych wojsku. W $1931 \mathrm{r}$. miasto liczyło ponad 13000 mieszkańców, ze znacznym odsetkiem niezasymilowanej ludności żydowskiej ${ }^{67}$. Zbudowany przez Rosjan obszerny kompleks koszarowy ulokowany był poza granicami miasta, na terenie nieistniejącego folwarku Wojciechowice (obecnie dzielnica Ostrołęki). Wyraźnie dzielił się na 3 człony, zwane - od stacjonujących w nich przed I wojną jednostek rosyjskich - koszarami kawaleryjskimi, saperskimi i piechoty. W maju $1921 \mathrm{r}$. koszary zostały przeznaczone na miejsce stałej dyslokacji 5. puł.

Początków obecności jednostek wojskowych w Ostrołęce można dopatrywać się w końcu XVIII w., gdy po III zaborze miasto znalazło się w granicach Królestwa Prus. Garnizon składał się wówczas ze szwadronu Bośniaków. W okresie 1807-1831 pozostawało wolne od wojska, zaś po zakończeniu wojny polsko-rosyjskiej $1831 \mathrm{r}$. ulokowano tu niewielki garnizon, którego głównym zadaniem była jakoby piecza nad pomnikiem poświęconym żołnierzom rosyjskim poległym $\mathrm{w}$ bitwie pod Ostrołęką (26 V $1831 \mathrm{r}$.) ${ }^{68}$. W latach sześćdziesiątych XIX w. ulokowano tu baterię artylerii konnej z 16. DK, a następnie dowództwo i I batalion 24. Symbirskiego pp. Oddziały te początkowo bytowały na kwaterach prywatnych; dopiero w latach siedemdziesiątych $\mathrm{w}$ mieście powstały drewniane budynki koszarowe, zlokalizowane w rejonie obecnej ul. Traugutta. Rozbudowa kompleksu oraz budowa linii kolejowej umożliwiła wkrótce skoncentrowanie w mieście całego pułku $^{69}$. W latach osiemdziesiątych XIX w. 24. pp opuścił miasto, a jego miejsce zajął 15. Szlisselburski pp z 4. DP. W tym czasie powstał pod Ostrołęką „niżegorodzki” obóz wojskowy, gdzie w doraźnych warunkach

skonalenia, zał. 3, 4; CAW, Dep. Kaw. MSWojsk., I.300.30.147, Dowództwo BK „Białystok” L.dz. 1432/tj.I.37 z 6 X 1937 r. - Sprawozdanie z koncentracji szwadronów ckm i strzelców wyborowych.

67 Drugi powszechny spis ludności z dn. 9.XII 1931 r. Województwo białostockie, Warszawa 1938, s. 1.

68 Z. Niedziałkowska, Ostrołęka. Dzieje miasta, Warszawa 1975, s. 169, 173.

69 Ежегодникъ русской армии на 1869 годъ, Санктпетербургь 1869, s. 551; J. Kijowski, Ostrotęka w dobie rozbiorowej (wybrane zagadnienia), „Rocznik Mazowiecki” 2011, nr 23, s. 40-47. 


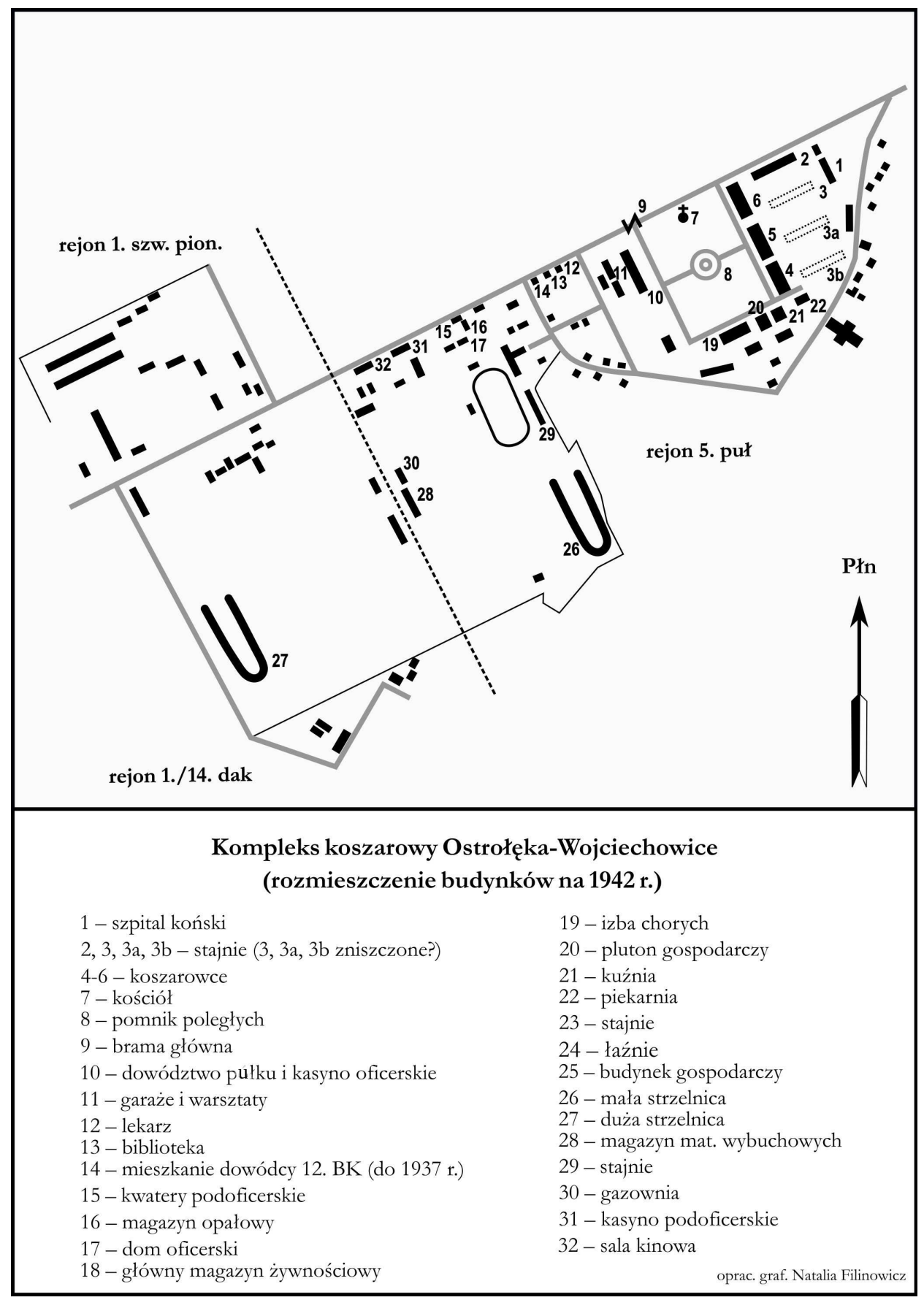


rozmieszczono 22. Niżegorodzki pp z 6. DP, a także - do czasu ukończenia budowy kolejnego kompleksu na południowym skraju miasta (tzw. koszary Benedona) - 16. Głuchowski pdrag. z 6. DK. Powiększenie garnizonu wymagało poważnych inwestycji budowlanych. Rozpoczęły się one w 1886 r. w Wojciechowicach, wsi położonej wzdłuż drogi wiodącej do Łomży. W 1890 r. pierwszą grupę obiektów oddano w użytkowanie 16. Głuchowskiemu pdrag. (w 1907 r. nastąpiła zmiana numeru porządkowego jednostki na 6.). Dwa lata później ruszyła budowa kolejnej grupy obiektów; została ukończona w 1900 r. i przeznaczona dla 22. Niżegorodzkiego pp i 10. batalionu saperów. Nowoczesny kompleks pomieścił dowództwo 6. DP (od 1906 r.), a od 1909 r. również dowództwo I Brygady Piechoty tej dywizji wraz z drugą jej jednostką - 21. Muromskim $\mathrm{pp}^{70}$. Kompleks w Ostrołęce-Wojciechowicach w przededniu I wojny światowej liczył - jeśli wierzyć Jerzemu Kijowskiemu - 21 budynków ceglanych, w tym: 8 koszarowych dwu- i trzykondygnacyjnych, 7 mieszkalnych, pralnię, lecznicę dla koni, magazyn i in. Budulcem była cegła na kamiennej podmurówce, $\mathrm{z}$ odpowiednimi instalacjami kanalizacyjnymi i grzewczymi, oświetlenie zapewniały lampy naftowe. W kompleksie znajdowały się dwie cerkwie, jedna wyświęcona w $1904 \mathrm{r}$. (po I wojnie przebudowana na szkołę powszechną), druga, otwarta krótko przed sierpniem 1914 r., w czasie wojny służąca jako lazaret i prawdopodobnie w 1916 r. przejęta przez władze kościelne i po odzyskaniu niepodległości konsekrowana jako kościół garnizonowy pw. św. Wojciecha. Obecnie świątynia, zachowująca wspomnianego patrona, służy jako kościół parafialny ojców pallotynów. $W$ chwili rozpoczęcia mobilizacji armii rosyjskiej w 1914 r. w garnizonie Ostrołęka w kompleksach koszarowych stacjonowało około 5000 żołnierzy ${ }^{71}$.

W czasie I wojny światowej znacznym zniszczeniom uległy drewniane obiekty koszarowe $\mathrm{w}$ samym mieście, niejednokrotnie na skutek podpalenia przez wycofujące się oddziały rosyjskie. Dodać należy, że dotąd nie odnaleziono informacji, czy po buncie niektórych elementów garnizonu ostrołęckiego w 1905 r. i spłonięciu części obiektów w mieście, zostały one odbudowane przed 1914 r. Wydaje się, iż kompleks w Ostrołęce-Wojciechowicach

70 Памятная книжка ломжинской губиерніи 1884, Аомжа 1884, s. 60-64; Памятная книжка ломжинской губиерніи 1886, Аомжа 1886, s. 98-100; Памятная книжка ломжинской губиерніи на 1906 годъ, Аомжа 1906, s. 109-139; Памятная книжка ломжинской губиерніи на 1909 годъ, Аомжа 1909, s. 169-212; J. Kijowski, op. cit., s. 47-49; Памятная книжка ломжинской губиерніи на 1912 годъ, Аомжа 1912, s. 171-210; Z. Niedziałkowska, op. cit., s. 182, 184-186, 192.

71 J. Kijowski, op. cit., s. 47-52. 
przetrwał okres wojny w niezłym stanie, wszak od jesieni 1916 r. użytkował je 1. puł. Legionów. Wojsko Polskie zajęło koszary w 1918 r., co uchroniło je przed poważniejszą dewastacją ze strony ludności cywilnej. Nie odnaleziono informacji, w jakim stopniu zostały zniszczone podczas krótkotrwałego pobytu Armii Czerwonej latem 1920 r. ${ }^{72}$

W 1921 r. Ostrołękę wyznaczono jako miejsce stałej dyslokacji formacji Wojska Polskiego, m.in. dowództwa brygady kawalerii, 5. puł. i dywizjonu artylerii konnej. Przywołana uprzednio za Jerzym Kijowskim liczba 21 budynków kompleksu koszarowego przed I wojną światową koliduje z danymi z 1931 r., podanymi przy okazji akcji nasadzania drzew w obiektach wojskowych. Komendant garnizonu ostrołęckiego złożył zamówienie na niemal 5000 sadzonek drzewek iglastych i liściastych, niezbędnych do właściwego urządzenia zieleni wokół 29 budynków w części zajętej przez 5. puł. i 24 obiektów w części administrowanej przez 12. dak ${ }^{73}$. Nierealne byłoby, by w bardzo trudnym ekonomicznie pierwszym dziesięcioleciu niepodległości władze wojskowe były zdolne do podwojenia liczby zabudowań w niewielkim garnizonie. Należy zatem uznać, iż rozbudowa kompleksu przez władze rosyjskie $\mathrm{w}$ kilku ostatnich latach przed wojną postępowała szybko.

Pierwotne przeznaczenie obiektów $\mathrm{w}$ wielu przypadkach uległo zmianie po 1921 r., np.: budynek dowództwa rosyjskiej dywizji został przystosowany do roli kasyna podoficerskiego, obszerny budynek mieszkalny zajęł: dowództwo pułku, kasyno oficerskie i mieszkania części kadry. Drewniane baraki stały się koszarami i magazynami plutonu łączności 5. puł., w murowanych budynkach kompleksu po kawalerii i piechocie rozlokowano szwadrony liniowe i szwadron zapasowy pułku. Ocalała także murowana, kryta ujeżdżalnia ze szklanym dachem, kuźnia, lecznica, warsztaty i liczne budynki o charakterze magazynowym. $W$ jednym $z$ istniejących do dziś budynków do 1937 r. ulokowane było dowództwo 12. BK i komenda placu. Willa dowódcy pułku i część mieszkań kadry mieściła się poza obrębem koszar, wzdłuż drogi łączącej Ostrołękę z Łomżą. Jedynym mankamentem części koszar zajętej przez 12., a od 1937 r. przez 3. baterię 14. dak, był brak krytej

72 Z. Niedziałkowska, op. cit., s. 199-206.

73 CAW, Dep. Budownictwa MSWojsk., I.300.63.90, Pismo dowódcy OK I L.dz. 14873/I.ZN/ 31/Szef.Bud. z 23 XI 1931 r. do II wiceministra SWojsk., zał.: Zapotrzebowanie kredytów na zakup sadzonek, potrzebnych do zadrzewienia budynków stanowiących własność Skarbu Państwa na terenie OK I; CAW, Dep. Budownictwa MSWojsk., I.300.63.90, Pismo komendanta garnizonu Ostrołęka L.dz. 463/31 z 19 X 1931 r. do Dowódcy OK I w sprawie zapotrzebowania na sadzonki. 
ujeżdżalni, wobec czego oddział musiał korzystać z maneżu 5. puł. Znaczną część prac nad konserwacją bądź polepszeniem stanu całego kompleksu garnizon wykonywał własnymi środkami i siłami. W zakres prac wykonanych samodzielnie należy zaliczyć elektryfikację budynków, budowę pralni i łaźni, wyposażenie warsztatów. Koszary zostały otoczone drewnianym parkanem z 7 bramami $^{74}$.

Znaczną pojemność zespołu wojciechowickiego potwierdza organizowanie właśnie tu podoficerskich szkół dywizyjnych przed 1937 r. Te same powody sprawiły, że po reorganizacji 12 . dak w 1 . baterię 14 . dak ${ }^{75}$ i włączeniu wraz z 5. puł. wiosną 1937 r. w skład Podlaskiej BK, w tych koszarach organizowano szkoły podoficerskie $\mathrm{ckm}$ brygady ${ }^{76}$. Obszerność kompleksu została uwzględniona $\mathrm{w}$ dwóch projektach zmian dyslokacyjnych. Pierwszym był pomysł DOK I na zamianę miejsc stałej dyslokacji 71. pp i dywizjonu 18. pal (Zambrów) oraz 5. puł. i 3. baterii 14. dak (Ostrołęka). Wnioskodawca wysunął liczne argumenty, przemawiające za wprowadzeniem proponowanej zmiany. Korzyścią byłoby stworzenie linii garnizonów nadgranicznych pułków piechoty od Działdowa po Łomżę. Teren na północ od Narwi pod Ostrołęką uznano za niekorzystny dla działań kawaleryjskich, ponadto $\mathrm{w}$ powiecie zambrowskim pułk ułanów miałby większe zasoby lepszego materiału końskiego, niż na ubogiej Kurpiowszczyźnie. Wiązało się to $\mathrm{z}$ koniecznością pewnych inwestycji budowlanych $\mathrm{w}$ koszarach zambrowskich (budowa lub dostosowanie stajni), natomiast wydział budownictwa DOK I uznał zasób lokalowy w Ostrołęce-Wojciechowicach za wystarczający dla pułku piechoty i dywizjonu artylerii. Ponadto przeniesienie pułku i baterii do Zambrowa zbliżałoby garnizon do macierzystej brygady

74 A. J. Dąbrowski, Święto pułkowe w 5. Pułku Ułanów Zasławskich, „Przegląd Kawalerii i Broni Pancernej" 1961, nr 23, s. 19; AIPMS, B.I.17/A/1, L. Kmicic-Skrzyński, Charakterystyka garnizonów, s. 1; J. Dziewirski, J. Kijowski, H. Maćkowiak, 5 Pułk Ułanów Zasławskich. Zarys dziejów, Ostrołęka 1994, s. 49-55; Z. Niedziałkowska, op. cit., s. 221.

CAW, Dep. Kaw. MSWojsk., I.300.30.30, Dep. Art. MSWojsk. L.dz. 701/tjn.Org.Og.35 Rozkaz wykonawczy o reorganizacji artylerii konnej na stopie pokojowej, zał. 1: Zestawienie składów osobowych artylerii konnej. Zał. 2 - składy dywizjonów, s. 1-2; Cf.: CAW, O I SG, I.303.3.60, Pismo DDO MSWojsk. L. 1709/Org.Tjn. z 18 III 1937 r. w sprawie reorganizacji artylerii konnej.

76 CAW, Dep. Kaw. MSWojsk. I.300.30.141, Rozkaz dowódcy 2. DK L. 129/Tjn. z 15 II 1933 r. wg rozdzielnika - Rozkaz organizacyjny do uruchomienia podoficerskich szkół ckm; CAW, Dep. Kaw. MSWojsk., I.300.30.141, Pismo dowódcy Podlaskiej BK L.dz. 2053/tj./I/37 z 18 XII 1927 r. do szefa Dep. Kaw. MSWojsk. w sprawie organizacji szkoły podoficerskiej ckm w 1938 r.; CAW, Dep. Kaw. MSWojsk., I.300.30.141, Pismo szefa Dep. Kaw. MSWojsk. L.dz. 2635/tj. wg rozdzielnika z 24 XII 1937 r. w sprawie organizacji szkół podoficerskich ckm w 1938 r., zał. 1. 
w Białymstoku, ułatwiając działalność szkoleniową oraz ewentualną mobilizację i koncentrację. Przemieszczenie zablokowała opinia szefa wydziału mobilizacyjnego Oddziału I Sztabu Głównego, który uznał zmiany dyslokacyjne za bezcelowe pod kątem korzyści mobilizacyjnych, za to wiążące się ze znacznymi nakładami na przystosowanie i rozbudowę koszar $\mathrm{w}$ obu miejscowościach ${ }^{77}$.

Drugi projekt pojawił się przy wdrażaniu reformy kawalerii w marcu 1937 r. i dotyczył przesunięcia miejsca stałej dyslokacji 1. szwadronu pionierów z Białegostoku do Ostrołęki. I wiceminister spraw wojskowych, podpierając się opinią Oddziału I Sztabu Głównego, wyraził zgodę na ów racjonalny wniosek. Jednak sprzeciw wobec relokacji wyraził dowódca Podlaskiej BK, który uprzednio nakazał organizację brygadowej szkoły ckm w części kompleksu, przeznaczonej dla pionierów. Wbrew oczekiwaniom dostosowywanie posaperskiej części koszar w Wojciechowicach zajęło wiele czasu, więc przeniesienie odłożono na wiosnę 1938 r. ${ }^{78} \mathrm{Z}$ dniem 1 maja $1938 \mathrm{r}$. 1. szwadron pionierów znalazł się w nowym miejscu dyslokacji; pod względem gospodarczym i macierzystym został przypisany do 5. puł. i wszedł w kompetencje dowódcy DOK I79. Zmiana miejsca stacjonowania szwadronu nie oznaczała automatycznej likwidacji problemów w dziedzinie wyszkolenia. Oddział odczuwał bowiem większe braki materiałowe niż w Białymstoku, nie dysponował również placem ćwiczeń nad Narwią, choć sama rzeka zapewniała dużo lepsze warunki wyszkolenia niż niewielki staw pionierski w koszarach im. J. Bema. Również w kwestii lokalowej szwadron zmagał się z pewnymi problemami, które uwidoczniły się po zarządzeniu w 1939 r. przygotowania pomieszczeń na zapasy materiałów wybuchowych i min oraz rozpoczę-

77 CAW, O I SG, I.303.3.431, Pismo DOK I L.dz.2132/Mob.Pl z 1 IV 1937 r. do szefa SG w sprawie zmian dyslokacyjnych na terenie DOK I, s. 7-10; CAW, O I SG, I.303.3.431, Pismo O I SG L.dz. 693/mob.37 z 12 IV 1937 r. w sprawie wniosków dyslokacyjnych na terenie DOK I - opinie szefa wydziału mobilizacyjnego O I SG, s. 2.

78 CAW, O I SG, I.303.3.431, Pismo O I SG L.dz. 561/mob.37 z 16 III 1937 r. do I wiceministra SWojsk. W sprawie przesunięcia szw. pion. BK Białystok do Ostrołęki; CAW, O I SG, I.303.3.431, Pismo DDO MSWojsk. L.6040/Org.Tjn. z 4 XI 1937 r. do DOK III w sprawie przeniesienia 1. szw. pion.; CAW, Dep. Kaw MSWojsk., I.300.30.141, Podlaska BK L.dz. 2053/tj./I/37 z 18 XII 1937 r. do szefa Dep. Kaw. MSWojsk. w sprawie miejsca uruchomienia szkoły podoficerskiej $\mathrm{ckm}$.

79 CAW, O I SG, I.303.3.431, Pismo DDO MSWojsk. L.6040/Org.Tjn. z 4 XI 1937 r. do DOK III w sprawie przeniesienia 1. szw. pion.; CAW, Oddział I SG, I.303.3.431, Pismo Oddziału I SG L.dz. 149/tj.38 w sprawie przesunięcia 1. szw. pion. BK Białystok do Ostrołęki; CAW, Oddział I SG, I.303.3.431, Pismo DDO MSWojsk. L.8135/Org.Tjn.37 z 9 II 1938 r. wg rozdzielnika w sprawie przeniesienia 1. szw. pion.; CAW, DOK III/40, Rozkaz tajny nr 31, Grodno 1 VIII 1938 r., s. 7. 
tej organizacji dodatkowego, zmotoryzowanego plutonu pionierów ${ }^{80}$. Trudności z pewnością spotęgowało przeniesienie do budynków zajmowanych przez 1. szw. pion. również plutonu pionierów 42. pp z całym sprzętem mobilizacyjnym ${ }^{81}$.

Poza wspomnianym powyżej niedostatkiem obiektów, 5. puł. nie dysponował garażami dla 4 taczanek i 15 wozów taborowych, przez co przedwcześnie niszczały na skutek czynników atmosferycznych; mimo to DOK I odrzucił wniosek o przyznanie środków na ich budowę. Pułk nie dysponował również działownią do garażowania przydzielonych armat przeciwpancernych wz. 36. Zgłaszający te obiekcje dowódca Podlaskiej BK wskazał również, iż dotychczasowe, drewniane magazyny amunicyjne pochłaniał grzyb. Inne dokumenty z ostatnich lat przed wybuchem wojny wskazują na liczne drobne uchybienia, m.in. $\mathrm{w}$ dziedzinie bytowej szeregowych, zaniedbań w części stajni itp. ${ }^{82}$

\section{b) Strzelnice i place ćwiczeń garnizonu}

Garnizon Ostrołęka miał w użytkowaniu trzy strzelnice. Pierwszą była odnowiona $\mathrm{w}$ drugiej połowie lat trzydziestych czteroosiowa strzelnica szkolna na placu ćwiczeń, umożliwiająca nawet prowadzenie części strzelań z broni maszynowej. Drugą - strzelnica pistoletowa (długość linii ognia $50 \mathrm{~m}$ ), umiejscowiona w części kompleksu zajętego przez 5. puł. W okresie okupacji niemieckiej po 1941 r. została ona wydłużona do $300 \mathrm{~m}$. Natomiast strzelania

80 CAW, Dep. Art. MSWojsk., I.300.34.147, Podlaska BK L.dz. 1801/I/tj.38 z 26 XI 1938 r. Sprawozdanie z wyszkolenia za okres letni 1938 r., zał. 1/e; CAW, Dep. Kaw. MSWojsk., I.300.30.58, MSWojsk. Dep. Kaw. L.dz. 118/mob. z 15 VII 1939 r. wg rozdzielnika w sprawie przygotowania magazynów na materiał wybuchowy w szw. pion.; CAW, Dep. Kaw. MSWojsk., I.300.30.58, Pismo Dowództwa Saperów MSWojsk. L.dz. 1088/Mob.Mat. z 5 VII 1939 r. do szefa Dep. Kaw. MSWojsk. w sprawie przygotowania magazynów i garaży.

81 CAW, O I SG, I.303.3.431, Pismo O I SG L.2399/tj, z 11 VIII 1939 r. w sprawie przeniesienia plut. pion. 42. pp do Ostrołęki; CAW, O I SG, I.303.3.431, Pismo O III SG L.2452/III.tj z 27 VII 1939 r. do szefa O I SG w sprawie przesunięcia plut. pion. 42. pp.

82 CAW, O I SG, I.303.3.647, Pismo DDO MSWojsk. L.dz. 2439/Org.Tjn z 30 III 1938 r. do szefa SG w sprawie realizacji zamierzeń budowlanych na rok 1938-1939; CAW, Dep. Kaw. MSWojsk., I.300.30.132, Podlaska BK L.dz. 1115/I.Tjn.37 z 30 VI 1937 r. - Sprawozdanie z wyszkolenia okresu zimowego 1936/37, s. 4; CAW, Korpus Kontrolerów MSWojsk., I.300.16.82, Sprawozdanie Korpusu Kontrolerów nr 4852 za rok 1937/1938, s. 29; CAW, GISZ, I.302.4.460, 12. BK L. 40/tjn. z 10 II 1937 r. - Wyniki niezapowiedzianego przeglądu dowódcy 12. BK w 5. puł. 29 I 1937 r., s. 1-3, 7; CAW, GISZ, I.302.4.456, 2. DK, L.dz. 1255/tjn z 12 XII 1936 r. - Sprawozdanie z inspekcji w 5. puł., s. 1-2; AIPMS, B.I.17/A/1, L. Kmicic-Skrzyński, Podlaska Brygada Kawalerii przed wojna 1939 r., s. 2-4, 5. 
szkolno-bojowe wykonywano na odległym o około $15 \mathrm{~km}$ obiekcie pod Dylewem, a niekiedy pododdziały wysyłano do odległego o ponad $50 \mathrm{~km}$ obozu ćwiczebnego Czerwony Bór. Po przeniesieniu do Wojciechowic, 1. szwadron pionierów użytkował prawem kaduka obszar nad Narwią nieopodal przystani rzecznej, gdzie mógł wykonywać wszelkie ćwiczenia wodne. W ocenie dowódcy brygady kompleks koszarowy Ostrołęka-Wojciechowice zapewniał lokatorom najlepsze warunki zakwaterowania i wyszkolenia spośród wszystkich oddziałów Podlaskiej BK ${ }^{83}$.

\section{Garnizony 9. psk im. gen. K. Pułaskiego w Grajewie i Osowcu}

\section{a) Grajewo i koszary I dywizjonu 9. psk}

Spośród oddziałów Podlaskiej BK najtrudniejszą sytuację pod względem warunków bytowych miał 9. psk. Niewystarczająca liczba obiektów w koszarach w Grajewie spowodowała, że część pułku dyslokowana była na terenie Twierdzy Osowiec. Rozdzielenie pułku stanowiło poważne utrudnienie w każdym aspekcie funkcjonowania jednostki. Samo miasteczko, stanowiące $\mathrm{w}$ okresie II RP siedzibę władz powiatu szczuczyńskiego, było ubogie, z około 8000 mieszkańców. Położony około $1 \mathrm{~km}$ na południe od miejscowości kompleks koszarowy przecięty był szosą prowadzącą do Osowca i dalej do Białegostoku. Wśród garnizonów II RP Grajewo zaliczało się do najbardziej narażonych na zaskoczenie przez potencjalnego nieprzyjaciela, gdyż koszary od granicy polsko-niemieckiej oddzielał dystans zaledwie $6,5 \mathrm{~km}$.

Początków rosyjskiego garnizonu w Grajewie należy doszukiwać się na przełomie lat osiemdziesiątych i dziewięćdziesiątych XIX w., w związku z koniecznością osłony szosy i linii kolejowej wiodącej z Prus Wschodnich przez budowaną Twierdzę Osowiec do Białegostoku. Początkowo garnizon nie był liczny i bytował na kwaterach prywatnych. Dopiero latem 1894 r. po letniej koncentracji 4. DK z Białegostoku do Grajewa na stałe został relokowany 10. Nowotroicko-Jekaterynosławski pdrag. (w 1907. r. numer porządkowy jednostki zmieniono na 4). Równolegle do Szczuczyna przeniesiono 4. pułk kozaków dońskich. Dragonów rozmieszczono w prowizorycznych

83 CAW, GISZ, I.302.4.460, 12. BK L. 40/tjn. z 10 II 1937 r. - Wyniki niezapowiedzianego przeglądu dowódcy 12. BK w 5. puł. 29 I 1937 r., s. 5; AIPMS, B.I.17/A/1, L. Kmicic-Skrzyński, Charakterystyka garnizonów, s. 1. 
warunkach w tzw. Obozie Potiomkina około $1 \mathrm{~km}$ na południe od miasteczka. Tu pozostał do wybuchu I wojny światowej, przy czym w końcu XIX w. rozpoczęto budowę zespołu koszarowego, częściowo wykorzystując jako budulec drewno, częściowo cegły. Budowa postępowała na tyle powoli, że do $1914 \mathrm{r}$. niecały pułk został w nich rozkwaterowany, a dwa spośród 6 szwadronów musiano rozmieścić w Osowcu ${ }^{84}$. Nie wiemy, w jakim stanie koszary przetrwały I wojnę światową i wojnę polsko-bolszewicką. Wydaje się, że dewastacja nie posunęła się zbyt daleko. Natomiast niedostateczną pojemność koszar (przy wzięciu pod uwagę potrzeb pułku kawalerii) pogłębiono na przełomie 1920 i 1921 r., gdy władze wojskowe lekkomyślnie zgodziły się na rozbiórkę części budynków, w tym jednego z niewielu murowanych - uszkodzonego koszarowca mogącego pomieścić 2 szwadrony i stajen na odnośną liczbę koni. $Z$ tego powodu zapewne zarzucono pomysł wykorzystania koszar jako miejsca stałej dyslokacji 10. puł. W związku z reorganizacją kawalerii i włączeniem strzelców konnych w obręb kawalerii samodzielnej w 1924 r., przeniesiono tu z Włodawy 9. psk, przy czym równocześnie jednostkę rozdzielono na dwa garnizony ${ }^{85}$. Można domniemywać, że z czasem zamierzano skupić oddział $\mathrm{w}$ jednym miejscu.

Początkowo w Grajewie stacjonowało dowództwo 9. psk z drużyną dowódcy, kwatermistrzostwo pułku oraz szwadrony 1., 2. i ckm, w Osowcu 3. i 4. szwadrony i pluton łączności. Na początku 1927 r. dokonano zmian dyslokacyjnych: w koszarach grajewskich rozmieszczono szwadrony 1., 2. i 3., w Osowcu 4. i szwadron ckm. Od 1933 r. pułk przyjął rozkwaterowanie, które właściwie nie zmieniło się do 1939 r., tj. w Grajewie znalazło się dowództwo i szwadrony 1., 3. i ckm, natomiast w Osowcu 2. i 4. Ostatnią zmianą dyslokacji było przeniesienie plutonu łączności do Grajewa po koncentracji letniej 1936 r., przy czym ciasnota w koszarach wymusiła rozlokowanie pododdziału w wynajętej w Grajewie kamienicy. To samo dotyczyło sformowanego w ostatnim okresie przed wojną plutonu kolarzy. W samych koszarach próbowano poradzić sobie z niedostateczną ilością przestrzeni m.in. piętrząc łóżka ${ }^{86}$.

84 R. Wróblewski, op. cit., s. 48, 50; AOBHW, XI.3.5 (stara sygn.), A. Dobroński, op. cit., s. 5-7; Памятная книжка ломжинской губиерніи на 1906 годъ, Һомжа 1906, s. 109-139; Памятная книжка ломжинской губиернии на 1909 годъ, Аомжа 1909, s. 169-212; D. Gawryluk, Wptyw lokalizacji..., s. 62-63.

85 T. Dudziński, 9. pułk strzelców konnych im. generała Kazimierza Pułaskiego, Grajewo 2018, s. $18-29,167$.

86 CAW, DOK III/35, Rozkaz tajny nr 21, Grodno 3 września 1936 r., s. 2; T. Dudziński, op. cit., s. $168-169$. 


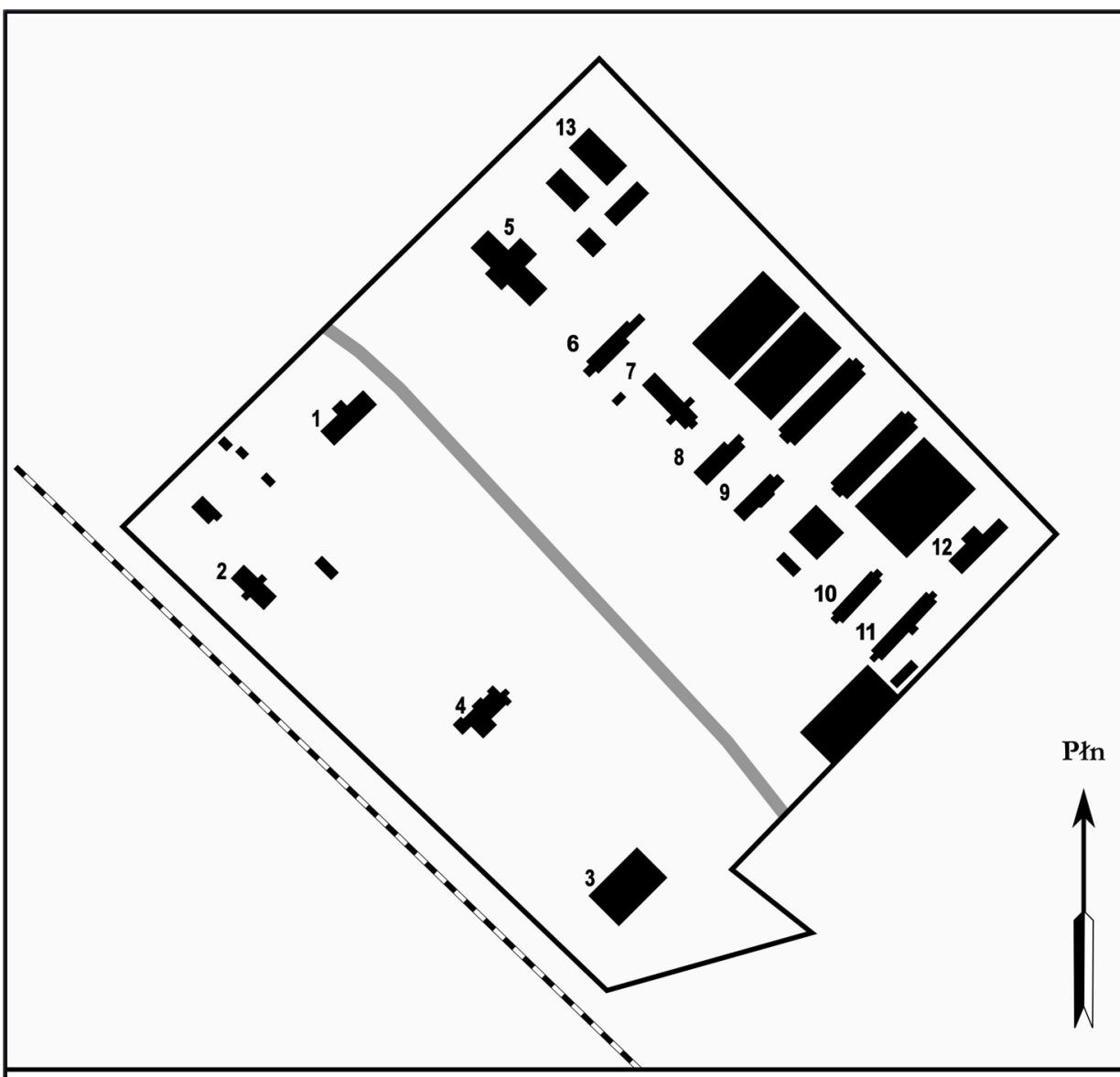

\section{Koszary I dywizjonu 9. pułku strzelców konnych w Grajewie}

1 - dowództwo pułku i kwatermistrzostwo

2 - budynek mieszkalny oficerski

3 - budynek mieszkalny podoficerski (Fundusz Kwaterunku Wojskowego)

4 - kasyno oficerskie

5 - ujeżdżalnia

6, 8, 9- budynki mieszkalne szeregowych

7 - kuchnia i świetlica

12 - budynek mieszkalny szwadronu gospodarczego, łaźnia, ambulatorium weterynaryjne, stajnia szwadronu gospodarczego

10,11 - stajnie

13 - magazyny 
Budulec większości użytkowanych obiektów stanowiło drewno, co przysparzało licznych kłopotów z racji wieloletnich zaniedbań w czynnościach konserwacyjnych. Budynkami murowanymi były: gmach dowództwa pułku, ujeżdżalna i kuźnia. Pierwszy z wymienionych znajdował się w zachodniej części kompleksu, podobnie jak willa dowódcy, mieszkania oficerskie, izba chorych, kasyno oficerskie i mieszkania podoficerskie. Tu też ulokowany był plac sportowy. Właściwe koszary zajmowały teren na wschód od szosy Grajewo - Osowiec: koszarowce, stajnie, kryta ujeżdżalnia, ambulatorium, magazyny itp. Gdy płk dypl. L. Kmicic-Skrzyński w 1929 r. obejmował dowództwo BK „Białystok”, ocenił stan koszar 9. psk jako opłakany, a zasługe podniesienia poziomu $\mathrm{w}$ kolejnych latach przypisywał jedynie działaniom ówczesnego dowódcy płk. dypl. Tadeusza Grabowskiego i dowódcy OK III gen. dyw. Aleksandra Litwinowicza. Inwestycje objęły m.in. elektryfikację koszar (1927-1928), budowę bloku mieszkalnego dla podoficerów z 16 mieszkaniami oraz kasyna podoficerskiego (1928-1930), remont dachów budynków (1931), budowę ogrodzenia z 9 bramami (1932-1934). Nadal jednak warunki bytowe były poniżej dopuszczalnego poziomu. Zawaleniem groził zagrzybiony budynek izby chorych, żołnierze musieli korzystać z wynajętej łaźni w miasteczku, a po wypowiedzeniu umowy na korzystanie z łaźni, utrzymywanie higieny szeregowych odbywało się $\mathrm{w}$ spartańskich warunkach. Zagrzybienie stwierdzono również w mieszkaniach oficerskich. Dodać można, że znaczną cześć prac sfinansowano ze środków pułku i rękami szeregowych ${ }^{87}$.

W ostatnim przed wojną sprawozdaniu Podlaskiej BK nie pojawiły się już informacje o konieczności poprawy warunków kwaterunkowych 9. psk, natomiast utyskiwano na rozdzielenie pułku na dwa garnizony oraz niedostatek materiałów szkoleniowych. Gruntowną poprawę odnotowano w dziedzinie zabezpieczenia higieny szeregowych. Równie wysoko oceniono stajnie i kuchnię. Nie poprawiła się natomiast sytuacja szwadronu gospodarczego, rozdzielonego częściami po różnych obiektach i kwaterującego w małych izbach na spiętrzonych łóżkach. Brakowało również komory gazowej oraz odpowiedniego magazynu amunicyjnego, w związku z czym przechowywano ją - wbrew zasadom - razem z bronią. Nie została uregulowana

87 CAW, Dep. Kaw. MSWojsk., I.300.30.132, Podlaska BK L.dz. 1115/I.Tjn.37 z 30 VI 1937 r. Sprawozdanie z wyszkolenia okresu zimowego 1936/37, s. 4; T. Dudziński, op. cit., s. 87-92, 166-174, 178-180. CAW, Dep. Kaw. MSWojsk., I.300.30.131, Dowództwo Podlaskiej BK L.dz. 1920/I.Tjn.37 z 20 XI 1937 r. - Czynniki organizacyjno-materialne wpływające na tok szkolenia i doskonalenia, zał. 3: Budownictwo. 
sytuacja plutonów specjalnych kwaterujących w miasteczku, mimo iż generowało to znaczne koszty. Wśród niezrealizowanych projektów pozostała koncentracja całego pułku w kompleksie grajewskim, wiążąca się z poważną inwestycją w budowę koszar, stajni i innych obiektów, choć zachowana dokumentacja wskazuje na podjęcie wstępnych kroków w tym kierunku. Wszelkie projekty pozostały jednak bez pozytywnej decyzji władz wojskowych wyższego szczebla 88 .

W przeciwieństwie do pozostałych oddziałów Podlaskiej BK, tylko 9. psk udało się przeprowadzić z powodzeniem procedurę nadania koszarom patrona. Działania w tym celu podjęto tuż po utworzeniu pułku w 1921 r., jednak wniosek utknął $\mathrm{w}$ ministerstwie na ponad dekadę, a oddział używał imienia patrona - gen. Kazimierza Pułaskiego nieoficjalnie. Być może tylko przypadek sprawił, że sprawie ponownie nadano bieg, w lutym $1933 \mathrm{r}$. MSWojsk. zatwierdziło bowiem nazwę kompleksu garnizonowego w Grajewie (Koszary im. gen. Kazimierza Pułaskiego), a 14 maja 1933 r. postać ta została uznana za patrona pułku, co wiązało się również z pozwoleniem na noszenie inicjałów „,KP” na naramiennikach mundurów ${ }^{89}$.

Obecnie czytelność zespołu grajewskiego jest częściowa. Rozwój miejscowości w kierunku południowym spowodował wchłonięcie elementów koszar w zabudowę miejską, a zachowało się jedynie kilka budynków murowanych. Wieś Koszarówka na południe od Grajewa stanowi wyznacznik południowego skraju przedwojennego kompleksu ${ }^{90}$.

\section{b) Twierdza Osowiec i koszary II dywizjonu 9. psk}

Informacje o rozlokowaniu II dywizjonu 9. psk w Osowcu są nader skromne. Wiadomo jedynie, że kwaterował on w tzw. Białych Koszarach na terenie Fortu III oraz $\mathrm{w}$ obiektach położonych $\mathrm{w}$ pewnej odległości

88 CAW, Dep. Art. MSWojsk., I.300.34.147, Podlaska BK L.dz. 1801/I/tj.38 z 26 XI 1938 r. - Sprawozdanie z wyszkolenia za okres letni 1938 r., załącznik 1/f - Warunki lokalne oddziałów; CAW, Dep. Kaw. MSWojsk., I.300.30.253, Pismo L.dz. 482/tj. z 22 III 1939 r. szefa Dep. Kaw. MSwojsk. gen. bryg. P. Skuratowicza do I wiceministra SWojsk. w sprawie inspekcji warunków wyszkolenia i zakwaterowania 10. puł. i 9. psk, s. 3-6. CAW, GISZ, I.302.4.1803, Rozbicie sum budżetu normalnego Dep. Budownictwa na okres 1937/1938; CAW, Dep. Kaw. MSWojsk., I.300.30.236, Wnioski Dep. Kaw. do budżetu na rok 1940/1941 dot. potrzeb z zakresu organizacji, wyszkolenia, wychowania i oświaty, k. 26, 29, 41, 43-44; CAW, Dep. Kaw MSWojsk., I.300.30.37, Spostrzeżenia dowódcy BK Białystok z organizacji i wyszkolenia brygady za rok 1934, b. d., s. 1 .

89 R. E. Stolarski, op. cit., s. 175; A. Dudziński, Generał Kazimierz Pułaski - szefem honorowym 9 psk w Grajewie, „Zapis. Grajewskie Zeszyty Historyczne” 2001, nr 2, s. 23-26.

90 D. Gawryluk, Wptyw lokalizacji..., s. 62-63. 
od tej lokacji na placu broni. Warunki w nich musiały być jeszcze cięższe niż w Grajewie, wśród kadry pułku utrzymywało się bowiem przeświadczenie o karnym wymiarze przesunięć personalnych do tego garnizonu. Z całą pewnością stan drewnianych obiektów koszarowych i mieszkalnych dla kadry stałej mógł skłaniać do takich przypuszczeń. Pomimo wielu różnorodnych obiektów w twierdzy (zachowały się one, chociaż odnotowano liczne zniszczenia w czasie I wojny światowej), podobnie jak w okresie carskim, również Wojsko Polskie odnotowywało poważne braki lokalowe ${ }^{91}$. Mimo to władze wojskowe nie widziały potrzeby poważniejszych inwestycji $\mathrm{w}$ obszarze przeznaczonym na rozkwaterowanie dywizjonu 9. psk.

Jeszcze w 1935 r., gdy obiekty koszar grajewskich stopniowo poddawano pracom remontowym, a poziom bytowania się podnosił, w Osowcu budynki były zawilgocone, zagrzybione, $\mathrm{z}$ nieszczelnymi dachami i niesprawną instalacją grzewczą. Inwestycje budowlane i remontowe były tu rzadsze niż w Grajewie. W 1932 r. powstała nowa stajnia dla jednego szwadronu i magazyn materiału kwaterunkowego, a kilka lat później budynek mieszkalny dla oficerów i dwa kolejne dla podoficerów. Mimo to, za sprawą remontów wykonywanych metodą gospodarczą, warunki lokalowe pododdziałów w Osowcu musiały się częściowo poprawić w ostatnich latach przed wojną, o czym świadczą fragmentaryczne zapisy w dokumentacji z tego okresu. W sprawozdaniach dowódca brygady płk. dypl. L. Kmicic-Skrzyński alarmował, że kwatery i stajnie wymagają kapitalnych remontów, natomiast w sprawozdaniu z wizytacji wiosną 1939 r. szef Departamentu Kawalerii ocenił stan zakwaterowania żołnierzy oraz jakość stajni jako dobry, choć wymagający dalszej poprawy. Podkreślił znaczenie inwestycji własnych pułku $\mathrm{w}$ podniesienie poziomu bytowego żołnierzy oraz wydatkowanie środków do zaadaptowania pomieszczeń dla plutonu armat ppanc. wz. $36^{92}$. Wydaje się, że w związku z brakiem środków

91 B. Perzyk, Twierdza Osowiec 1882-1915, Warszawa 2004, s. 49-51, 115-116, 190-211, 277-283, 293-294.

92 CAW, Dep. Art. MSWojsk., I.300.34.147, Podlaska BK L.dz. 1801/I/tj.38 z 26 XI 1938 r. Sprawozdanie z wyszkolenia za okres letni 1938 r., zał. 1/f - Warunki lokalne oddziałów; CAW, Dep. Kaw. MSWojsk., I.300.30.132, Podlaska BK L.dz. 1115/I.Tjn.37 z 30 VI 1937 r. - Sprawozdanie z wyszkolenia okresu zimowego 1936/37, s. 4; CAW, Dep. Kaw. MSWojsk., I.300.30.253, Pismo L.dz. 482/tj. z 22 III 1939 r. szefa Dep. Kaw. MSwojsk. gen. bryg. P. Skuratowicza do I wiceministra SWojsk. w sprawie inspekcji warunków wyszkolenia i zakwaterowania 10. puł. i 9. psk, s. 3, 6; T. Dudziński, 9. Pułk strzelców..., s. $187-189$. 


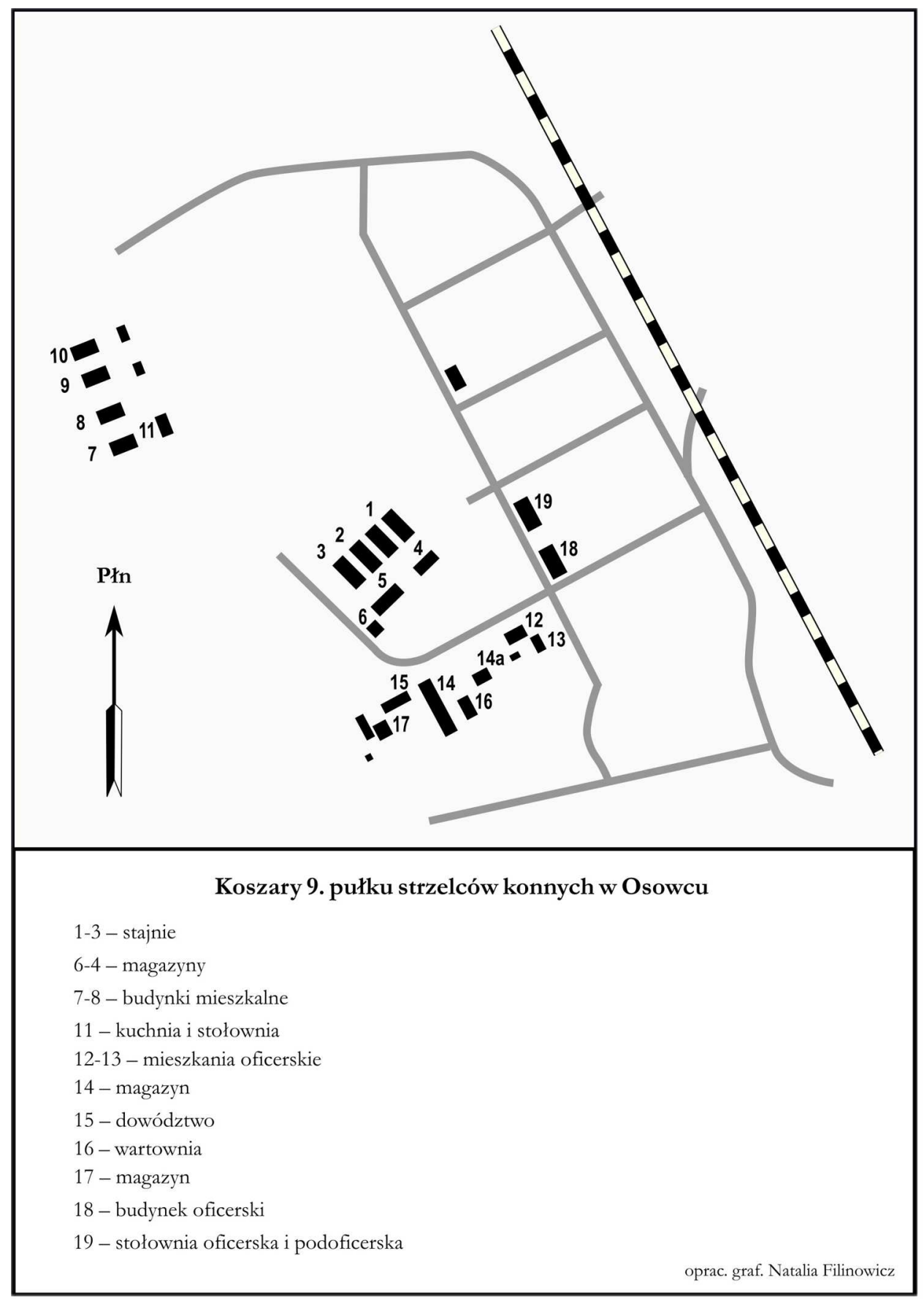


przewidzianych na inwestycje budowlane w garnizonach Podlaskiej BK w roku budżetowym 1937-1938, remonty obiektów 9. psk w Osowcu musiały zostać przeprowadzone w roku 1938-1939, bądź też kwoty zostały „ukryte” w innych kategoriach wydatków ${ }^{93}$.

\section{c) Strzelnice i place ćwiczeń w użytkowaniu pułku}

Nieco lepiej niż warunki zakwaterowania przedstawiała się zasobność 9. psk w obiekty szkoleniowe. Początkowo strzelania szkolne w Grajewie wykonywano w "dzikim”, niezamieszkałym terenie na tzw. piaskach w rejonie toru kolejowego, gdyż w kompleksie znajdowała się jedynie strzelnica 100-metrowa. W 1938 r. została ona rozbudowana do 4 osi a linia ognia wydłużona do $300 \mathrm{~m}$. Dzięki temu całkowicie zaspokojono potrzeby garnizonu w zakresie strzeleckim. Do wyszkolenia taktycznego wykorzystywano przyległy do ogrodzenia koszar plac ćwiczeń o powierzchni 150 ha ${ }^{94}$.

W dyspozycji komendanta garnizonu Osowiec (równocześnie komendanta Centralnej Szkoły Podoficerskiej KOP) znajdowały się strzelnice: małokalibrowa na $100 \mathrm{~m}$, szkolna na $300 \mathrm{~m}$ i szkolno-bojowa; na terenie fortecznym ulokowany był również plac ćwiczeń. Dla uniknięcia wyjazdów do odległych poligonów, Rosjanie w końcu XIX w. podjęli starania o stworzenie poligonu artyleryjsko-strzeleckiego na potrzeby obsady twierdzy. Został on ulokowany na prawym brzegu Biebrzy w rejonie między wsią Sośnia a szosą grajewską z osiami ognia skierowanymi w kierunku wsi Białaszewo (północ-północny-zachód). Stopniowo metodą gospodarczą rozbudowywano tu szkolne obiekty fortyfikacyjne; z czasem stały się one pełnowartościowymi umocnieniami i zostały wykorzystane bojowo podczas I wojny światowej (tzw. Reduta Sośnieńska). Natomiast usiłowania zorganizowania strzelnicy artyleryjskiej napotkały na szereg trudności, zwłaszcza w zakresie pozyskania odpowiednio obszernego terenu. Wykup gruntów i karczowanie lasu (434 ha) miało następować stopniowo, jednak technika i taktyka artyleryjska postępowały szybciej niż prace, toteż dowództwo twierdzy zarzuciło ostatecznie pomysł, a karłowaty poligon funkcjonował jedynie jako dodatkowy plac

93 CAW, GISZ, I.302.4.1803, Rozbicie sum budżetu normalnego Dep. Budownictwa na okres 1937/1938; J. Chęciński, op. cit., s. 100 i nast.

94 CAW, Dep. Kaw. MSWojsk., I.300.30.253, Pismo L.dz. 482/tj. z 22 III 1939 r. szefa Dep. Kaw. MSwojsk. gen. bryg. P. Skuratowicza do I wiceministra SWojsk. w sprawie inspekcji warunków wyszkolenia i zakwaterowania 10. puł. i 9. psk, s. 3-6. 
ćwiczeń i strzelnica szkolno-bojowa ${ }^{95}$. W II RP ograniczony obszar poligonu był intensywnie wykorzystywany przez garnizon osowiecki, szczególnie strzelnica 8-osiowa o 300-metrowej linii ognia. Mimo prymitywnego wyposażenia, obiekt - za zgodą komendanta garnizonu Osowiec - był podstawową strzelnicą szkolno-bojową i bojową dla wszystkich oddziałów Podlaskiej BK, toteż gros koncentracji tej wielkiej jednostki organizowano w pobliżu tego obiektu. Wykonywano na niej również wszystkie strzelania bojowe $\mathrm{z}$ otrzymanych $\mathrm{w}$ ostatnich latach przed wojną armat ppanc. $37 \mathrm{~mm}$ wz. 36 oraz koncentracje szkół ckm, strzelców wyborowych itd. Z tego powodu w 1939 r. w Osowcu ulokowano szkołę obsług armat ppanc. wz. 36 Nowogródzkiej, Wileńskiej i Podlaskiej BK. Niepowodzeniem zakończyły się usiłowania dowódcy brygady pozyskania środków, potrzebnych do prac nad wydłużeniem długości linii ognia do $400 \mathrm{~m}$, dostosowania strzelnicy do prowadzenia ognia pułapowego oraz przekształcenia całego obszaru w poligon wielkiej jednostki ${ }^{96}$.

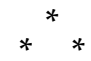

95 B. Perzyk, op. cit., s. 57; AIPMS, B.I.17/A/1, L. Kmicic-Skrzyński, Charakterystyka garnizonów, s. $5-6$.

96 CAW, Dep. Kaw. MSWojsk., I.300.30.147, BK Białystok L.dz. 183/tj. z 29 V 1932 r. - Sprawozdanie z wyszkolenia za okres zimowy 1931/32; T. Dudziński, 9. Pułk strzelców konnych..., s. 157-160, 179-181; CAW, Dep. Kaw. MSWojsk., I.300.30.132, Podlaska BK L.dz. 1115/I.Tjn.37 z 30 VI 1937 r. - Sprawozdanie z wyszkolenia okresu zimowego 1936/37, s. 4; CAW, Dep. Art. MSWojsk., I.300.34.147, Podlaska BK L.dz. 1801/I/tj.38 z 26 XI 1938 r. - Sprawozdanie z wyszkolenia za okres letni 1938 r., zał. 1/a, s. 1-2; CAW, Dep. Kaw. MSWojsk., I.300.30.97, Podlaska BK L.dz. 900/Tj.I.39 z 25 V 1939 r. - Wytyczne szkolenia na okres letni 1939 r., s. 8-16; CAW, Dep. Kaw. MSWojsk., I.300.30.253, Pismo L.dz. 482/tj. z 22 III 1939 r. szefa Dep. Kaw. MSwojsk. gen. bryg. P. Skuratowicza do I wiceministra SWojsk. W sprawie inspekcji warunków wyszkolenia i zakwaterowania 10. puł. i 9. psk, s. 3; CAW, Dep. Kaw. MSWojsk., I.300.30.128, Podlaska BK L.dz. 1/I/tj.39 z 2 I 1939 r. Rozkaz organizacyjny dla XII kursu szkoły podofic. c.k.m. i samodzielnego plutonu szkolnego działonowych armatek ppanc. $37 \mathrm{~mm}$ na r. 1939, s. 1-4, 6-9, zał. 2, s. 1. CAW, Dep. Kaw MSWojsk., I.300.30.141, Dowództwo Podlaskiej BK L.dz. 117/I.tjn.37 z 1 VII 1937 r. do szefa Dep. Kaw. MSWojsk. - Sprawozdanie z przebiegu i wyników szkolenia obsługi armatki 37 mm w szkole podoficerskiej c.k.m. brygady, s. 1-3. CAW, Dep. Kaw. MSWojsk., I.300.30.147, BK „Białystok” L.dz. 317/tj. z 9 VII 1934 r. - Terminy i miejsca postoju oddziałów na koncentrację BK „Białystok” w 1934 r.; CAW, Dep. Kaw. MSWojsk., I.300.30.147, Dowództwo BK „Białystok” L.dz. 500/tj. z 14 VII 1934 r. - Wytyczne na koncentrację letnią 1934 r., s. 1-2; CAW, Dep. Kaw. MSWojsk., I.300.30.131, Podlaska BK L.dz. 1920/I.Tjn.37 z 20 XI 1937 r. - Czynniki organizacyjno-materialne wpływające na tok szkolenia i doskonalenia, zał. 3. 
Baza kwaterunkowa oddziałów Podlaskiej BK była różnorodna. W decydującej mierze poziom bytowy danego oddziału zależał od lokalizacji garnizonu, obszerności przydzielonych koszar, ich budulca czy założeń technicznych obiektów zależnych na ogół od czasu powstania samych budowli. Zgoła odmiennie wyglądał stan zakwaterowania 14. dak w nowoczesnych koszarach im. gen. J. Bema, od 10. puł., rozmieszczonego w drewnianych obiektach koszar im. marsz. J. Piłsudskiego. Poziom bytowy szeregowych, bez wątpienia wpływający na stosunek do służby wojskowej, w znacznym stopniu uzależniony był od dbałości dowódców oddziałów o konserwację i remont obiektów mieszkalnych, a także od umiejętności pozyskania środków na ten cel od instytucji administracyjnych armii. Oczywiście w warunkach trudności gospodarczych II RP nie było to zadanie łatwe, lecz - jak udowodniłem - wykonalne. Niedocenianym czynnikiem jest pewnego rodzaju "szczęście” poszczególnych oddziałów w kwestii przydziału miejsc stałej dyslokacji w latach 1921-1922. Podkreślić należy, że zdecydowanie najmniej go miał 9. psk. Pułk powstał najpóźniej i zapewne to było powodem ulokowania go w garnizonach w Grajewie i Osowcu w 1924 r. Aż do 1939 r. borykał się on z najpoważniejszymi - wśród oddziałów Podlaskiej BK - problemami natury bytowej. Całościowo nie można więc dokonać jednoznacznej oceny warunków zakwaterowania oddziałów brygady, gdyż były bardzo zróżnicowane. Najlepszymi warunkami bytowymi dysponował 5. puł. w koszarach w Ostrołęce-Wojciechowicach oraz 14. dak w koszarach im. gen. Bema w Białymstoku, najgorszymi - 9. psk w Grajewie i Osowcu. Oddział ten tylko w pewnym stopniu przodował $\mathrm{w}$ tej niechlubnej statystyce przed 10. puł., którego koszary - choć obszerne i niezagospodarowane w całości - prezentowały równie ponury obraz bytowy szeregowych. We wszystkich przypadkach nieliczne inwestycje były spóźnione.

Jeszcze gorzej przedstawiały się możliwości szkoleniowe, przy czym poziom w tej kategorii nie pokrywał się z poziomem zabezpieczenia bytowego. W tej kategorii stosunkowo najlepiej ulokowany był 9. psk, dysponujący przykoszarowymi strzelnicami i rozległym, acz „dzikim” placem ćwiczeń, oraz stosunkowo nieodległym "mini-poligonem” pod Osowcem, choć pozostającym poza władzą dowódcy pułku. Stosunkowo komfortową sytuacją mógł poszczycić się również 5. puł. w Ostrołęce, dysponujący zarówno strzelnicami szkolnymi na obszarze garnizonu, jak również nieodległymi strzelnicami szkolno-bojowymi w Dylewie i Czerwonym Borze. Z punktu widzenia zapotrzebowania na obiekty strzeleckie i place ćwiczeń w najgorszej sytuacji znajdowały się oddziały brygady garnizonu Białystok. Usiłowania pozyskania odpowiednich terenów dla niwelacji braków nie zakończyły się powo- 
dzeniem do wybuchu wojny, wobec czego zarówno 10. puł., jak i 14. dak były pod tym względem najbardziej poszkodowane. Pierwszy z wymienionych musiał odbywać gros szkolenia strzeleckiego corocznie na przedoboziu przed koncentracją letnią, drugi - wyjeżdżać całością sił lub pododdziałami na odpowiednie poligony. Rzutowało to negatywnie na poziom wyszkolenia strzeleckiego oraz zgrania pododdziałów.

W żadnym razie tematu infrastruktury szkoleniowej i koszar Podlaskiej Brygady Kawalerii nie można uznać za wyczerpany. Archiwa kryją wiele zespołów, w których można będzie znaleźć kolejne informacje, zarówno dotyczące planów budowlanych czy konserwacyjnych, jak i rozbudowy infrastruktury szkoleniowej. Wypadałoby również ustalić związek pomiędzy lokalizacją danego garnizonu oraz stanem bytowym i szkoleniowym oddziałów, a ocenami poziomu wyszkolenia przez dowódców związków taktycznych i generałów inspekcjonujących. Te oraz szereg innych pytań badawczych nadal oczekują na odpowiedzi. Wypada wyrazić nadzieję, że archiwa w końcu otworzą podwoje i umożliwią wykonanie tej pracy.

\section{Bibliografia}

\section{Źródła archiwalne}

Archiwum Instytutu Polskiego i Muzeum im. gen. Sikorskiego w Londynie:

- Zespół relacji z kampanii wrześniowej (B.I.17/A/1).

Archiwum Ośrodka Badań Historii Wojskowej Muzeum Wojska w Białymstoku:

- Zespół akt różnych (XI.3).

Centralne Archiwum Wojskowe Wojskowego Biura Historycznego:

- Zespół Dowództwa Okręgu Korpusu nr III

- Zespół Biura Personalnego MSWojsk.

- Zespół Departamentu Artylerii MSWojsk.

- Zespół Departamentu Budownictwa MSWojsk.

- Zespół Departamentu Kawalerii MSWojsk.

- Zespół Generalnego Inspektoratu Sił Zbrojnych

- Zespół Korpusu Kontrolerów MSWojsk.

- Zespół Oddziału I Sztabu Głównego.

\section{Źródła drukowane}

Drugi powszechny spis ludności z dn. 9.XII 1931 r. Województwo białostockie, Warszawa 1938. 
Ежегодникъ русской арміи на 1869 годъ, Санктпетербургь 1869.

Памятная книжка гродненской губерніи на 1847 годь, Гродно 1847.

Памятная книжка гродненской губерніи на 1870 г., Гродно 1870.

Памятная книжка ломжинской губиерніи 1884, Аомжа 1884.

Памятная книжка ломжинской губиерніи 1886, Аомжа 1886.

Памятная книжка ломжинской губиерніи на 1906 годъ, Аомжа 1906.

Памятная книжка ломжинской губиерніи на 1909 годъ, Аомжа 1909.

Памятная книжска ломжинской губиерніи на 1912 годъ, Аомжа 1912.

\section{Opracowania}

Chęciński J., Budownictwo wojskowe w Polsce (1918-1939), Warszawa 1966.

Dąbrowski A. J., Historia 10 Pułku Ułanów Litewskich, Londyn 1982.

Dąbrowski A. J., Święto pułkowe w 5. Pułku Ułanów Zasławskich, „Przegląd Kawalerii i Broni Pancernej" 1961, nr 23.

Dobroński A., Białystok. Historia miasta, Białystok 2001.

Dobroński A., Filipow K., „Dziesiątacy” z Białegostoku. 10 Pułk Ułanów Litewskich, Białystok 1992.

Dudziński A., Generał Kazimierz Pułaski - szefem honorowym 9 psk w Grajewie, "Zapis. Grajewskie Zeszyty Historyczne" 2001, nr 2.

Dudziński T., 9. pułk strzelców konnych im. generała Kazimierza Pułaskiego, Grajewo 2018.

Dziewirski J., Kijowski J., Maćkowiak H., 5 Pułk Ułanów Zasławskich. Zarys dziejów, Ostrołęka 1994.

Gawryluk D., Wplyw lokalizacji carskich koszar na strukture przestrzenna wybranych miast województwa podlaskiego, „Teka Komisji Architektury, Urbanistyki i Studiów Krajobrazowych" 2015, t. XI, nr 1.

Gawryluk D., Współczesne modernizacje zabytkowych zespołów koszarowych - analiza wybranych realizacji na terenie Polski, „Teka Komisji Architektury, Urbanistyki i Studiów Krajobrazowych" 2015, t. XI, nr 1.

Kazimierski J., Straty biologiczne i materialne na obszarze obecnego województwa ostrołęckiego w latach II wojny światowej, „Rocznik Mazowiecki” 1998, t. 10, s. 84-86.

Kijowski J., Ostrołęka w dobie rozbiorowej (wybrane zagadnienia), „Rocznik Mazowiecki” 2011, nr 23.

Kraśnicka U., Organizacja rzymskokatolickiego duszpasterstwa wojskowego na terenie DOK III Grodno w latach 1921-1939, "Zeszyt Naukowy Muzeum Wojska” 1998, z. 11.

Kucharski S., Koszary, [w:] Odznaki kawalerii, t. 22: 10 pułk ułanów (seria: Wielka Księga Kawalerii Polskiej 1918-1939), Warszawa 2019.

Kusiński W., Rozwój przestrzenny miasta Białegostoku, „Studia i Materiały do Dziejów Miasta Białegostoku", t. I, 1968.

Mościcki H., Białystok. Zarys historyczny, Białystok 1933.

Niedziałkowska Z., Ostrołęka. Dzieje miasta, Warszawa 1975. 
Perzyk B., Twierdza Osowiec 1882-1915, Warszawa 2004.

Stolarski R. E., Nazwy obiektów wojskowych w II Rzeczypospolitej, „Mars” 1993, nr 1.

Szczepański K., Wspomnienia o 14 dywizjonie artylerii konnej, Białystok 2004.

Tomecka B., Zespół koszarowy przy ul. Kawaleryjskiej. Studium historyczno-przestrzenne opracowane na zlecenie 18 Brygady Zmechanizowanej, Białystok 1995.

Tomecka B., Zespół koszarowy przy ulicy Bema. Studium historyczno-przestrzenne opracowane na zlecenie Podlaskiego Oddziału Straży Granicznej im. gen. dyw. H. Minkiewicza, Białystok 1996.

Wojciechowski J. S., 10. Pułk Ułanów Litewskich, Oświęcim 2014.

Wróblewski R., Zarys historii carskiego garnizonu w Białymstoku w latach 1864-1914, „Militaria XX wieku” 2012, nr 1.

Zwolski M., Śladami zbrodni okresu stalinowskiego w województwie białostockim, Białystok 2013.

\title{
Strony www
}

www.koszary.zambrow.org

\section{Barracks and training facilities of the Podlaska Cavalry Brigade in the years 1937-1939. Selected aspects}

\begin{abstract}
Summary
The article contributes to the topic of living conditions and training facilities of the Polish Armed Forces cavalry by studying the case of the Podlaska Cavalry Brigade in years 1937-1939, nearing the end of its peacetime activity before the outbreak of World War II. The author examines the construction of Russian garrisons and their barracks in the late 19th and early 20th centuries, the functions of military structures and building materials used, as well as the condition of buildings upon their capture by the Polish Armed Forces. The article probes into the limited construction projects and inadequate renovation and maintenance funds, both of which contributed to varying, but overall poor, living conditions of soldiers. It also discusses the training facilities (shooting ranges and training grounds) throughout a number of garrisons, showing evidence of their insufficient development and negative impact on the training process.
\end{abstract}

Lukasz Radulski (ur. 1981 r.) - dr nauk humanistycznych. Historyk, kierownik Ośrodka Badań Historii Wojskowej Muzeum Wojska w Białymstoku. Podejmuje głównie problematykę badawczą Wojska Polskiego okresu II Rzeczypospolitej oraz kampanii wrześniowej $1939 \mathrm{r}$.

e-mail: lradulski@mwb.com.pl 